University of Louisville

ThinkIR: The University of Louisville's Institutional Repository

Electronic Theses and Dissertations

$5-2010$

\title{
Bum hunters : the simulations and neutralizations of negative actions taken against the homeless on YouTube.
}

Elizabeth Anne Griffith 1986-

University of Louisville

Follow this and additional works at: https://ir.library.louisville.edu/etd

\section{Recommended Citation}

Griffith, Elizabeth Anne 1986-, "Bum hunters : the simulations and neutralizations of negative actions taken against the homeless on YouTube." (2010). Electronic Theses and Dissertations. Paper 534.

https://doi.org/10.18297/etd/534

This Master's Thesis is brought to you for free and open access by ThinkIR: The University of Louisville's Institutional Repository. It has been accepted for inclusion in Electronic Theses and Dissertations by an authorized administrator of ThinkIR: The University of Louisville's Institutional Repository. This title appears here courtesy of the author, who has retained all other copyrights. For more information, please contact thinkir@louisville.edu. 


\title{
BUM HUNTERS: \\ THE SIMULATIONS AND NEUTRALIZATIONS \\ OF NEGATIVE ACTIONS TAKEN AGAINST THE HOMELESS \\ ON YOUTUBE
}

\author{
By \\ Elizabeth Anne Griffith \\ B.A., Ohio Wesleyan University, 2008

\begin{abstract}
A Thesis
Submitted to the Faculty of the

College of Arts and Sciences of the University of Louisville in Partial Fulfillment of the Requirements
\end{abstract} \\ for the Degree of
}

Master of Arts

Department of Sociology

University of Louisville

Louisville, Kentucky

May 2010 


\section{BUM HUNTERS: \\ THE SIMULATIONS AND NEUTRALIZATIONS \\ OF NEGATIVE ACTIONS TAKEN AGAINST THE HOMELESS \\ ON YOUTUBE}

\section{By}

Elizabeth Anne Griffith

B.A., Ohio Wesleyan University, 2008

A Thesis Approved on

April 15, 2010

by the following Thesis Committee:

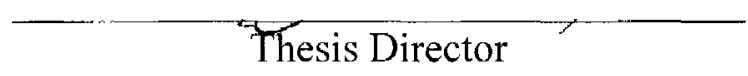




\section{DEDICATION}

This thesis is dedicated to

those who have lit my flame for social justice,

added fuel to my fire,

helped light the path when my flame was not strong enough,

and knew the flame would not burn out, even when I doubted it myself. 


\section{ACKNOWLEDGEMENTS}

Thank you to Dr. Mary Howard and Chaplain Jon Powers for opening my eyes to the

plight of those without homes. Thank you to Dr. Mark Austin, Dr. Ryan Schroeder, and Dr. Viviana Andreescu for being so encouraging and supporting me through this process.

Thank you to my family, who has supported me in all that I do. 


\section{ABSTRACT \\ BUM HUNTERS: \\ THE SIMULATIONS AND NEUTRALIZATIONS \\ OF NEGATIVE ACTIONS TAKEN AGAINST THE HOMELESS \\ ON YOUTUBE}

April 15, 2010

\section{Elizabeth Anne Griffith}

Due to of the rise in numbers of persons experiencing homelessness, communities are working to restrict access that homeless individuals have to public spaces. Many cities across the nation have criminalized aspects of homelessness in attempts to 'beautify' the areas. Starting in 2001, four videos were created and sold illustrating "bum fighting" in which homeless people were depicted fighting or performing stunts in return for alcohol and/or drugs (NCH, 2007). The National Coalition for the Homeless directly links the release of these videos to the increase of attacks against the homeless, many videotaping the ordeal, imitating the original videos. In this paper, I analyze 35 YouTube videos that display negative actions taken against homeless individuals. Findings indicate that those who take negative actions against homeless individuals neutralize their actions, which situates their actions as appropriate actions to be taken against the homeless. 


\section{TABLE OF CONTENTS}

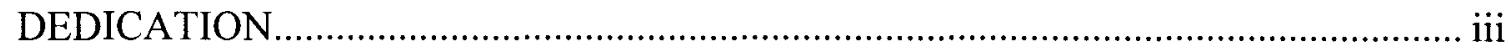

ACKNOWLEDGEMENTS...............................................................................

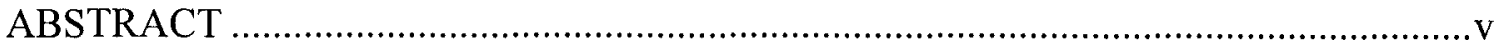

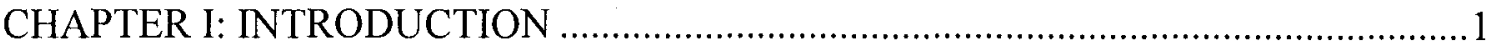

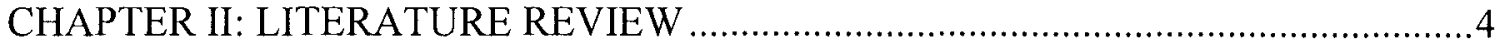

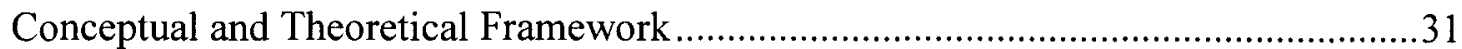

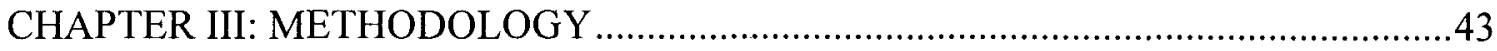

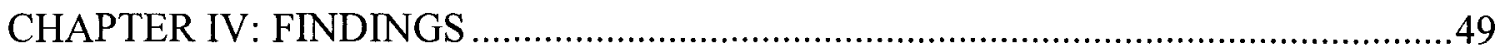

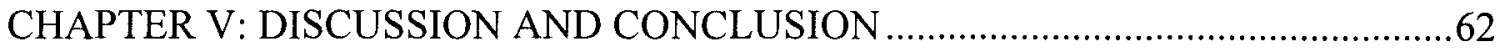

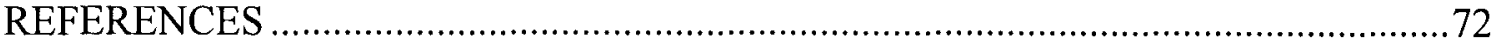

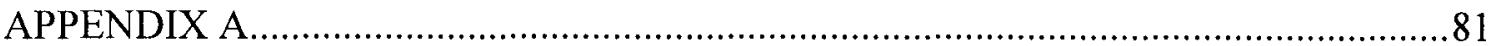

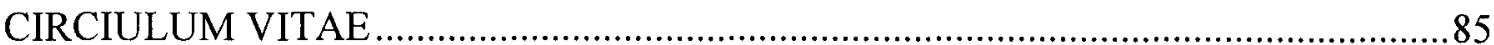




\section{LIST OF TABLES}

TABLE

PAGE

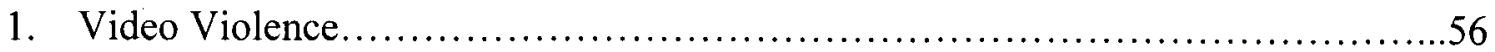




\section{CHAPTER I}

\section{INTRODUCTION}

Videos that display violence against the homeless have created a reality in which many view these actions as necessary in cleaning up the streets. This reality is formed through the viewing of these videos and then simulating them, creating hyperreality (Baudrillard, 2006). Persons experiencing homelessness are viewed in direct violation of community order because they are strangers and their actions and appearances are clear signs of their 'outsider' status. The presence of homeless persons in a neighborhood is aligned with breakdown of order in the community (Wilson \& Kelling, 1982).

Since the late 1970s, homelessness has become much more visible because there are greater numbers of individuals living on the street or in shelters and there are more Americans experiencing it than in the past (Blau, 1992). When looking at homelessness, people have a tendency to blame the victim, by attributing the reasons that a person is homeless to be situational as an individual problem instead of a societal issue (Blau, 1992; Lee, et al., 1990; 1992). The homeless are seen as a symptom of societal disorder, threatening and criminal in nature; because of these beliefs, efforts are taken to remove them from sight. When society fears the homeless, any interactions with the population 
could provoke fear or the threat of danger (Wright, 2000). Due to of the rise in numbers of persons experiencing homelessness, communities are working to restrict access that homeless individuals have to public spaces (Wachholz, 2005). Many cities across the nation have criminalized aspects of homelessness, which prohibit individuals from committing such acts as loitering, panhandling, and sleeping outside.

There is a documented relationship between increased legislation criminalizing homelessness and the increasing numbers of violent acts against the homeless $(\mathrm{NCH}$, 2007). In a 2007 report executive director of the National Coalition for the Homeless (NCH) explained, "It seems that disturbed violent people take a cue from their cities' responses to homelessness and become emboldened with more violent attacks if the city has portrayed homeless people as the cause of unemployment, decreasing property values, or vacant storefronts" (p. 77).

The $\mathrm{NCH}$ produces a yearly report detailing hate crimes and violence against people experiencing homelessness. Since 1999, the NCH has documented 880 violent acts throughout the United States and 244 deaths of people experiencing homelessness through violent acts against them. The number of attacks increased from 2006 to 2007 by 13 percent and the number of fatal attacks rose 40 percent in the same period. The vast majority of attackers were male and their stated reasons for attacks against those experiencing homelessness were because they were bored, because the victim is homeless, just for the 'fun' of it, or just because they 'could' (NCH, 2007).

Starting in 2001, four videos were created and sold illustrating "bum fighting" in which homeless people were depicted fighting or performing stunts in return for alcohol and/or drugs $(\mathrm{NCH}, 2007)$. The $\mathrm{NCH}$ directly links the release of these videos to the 
increase of attacks against the homeless throughout the nation. "These videos represent a new form of dehumanization and exploitation against homeless individuals" $(\mathrm{NCH}, 2007$ : 35). In addition to the original videos, many individuals have made their own versions and posted them on YouTube. There are many different types of video clips on YouTube that display harassment and violence towards homeless persons, however; I specifically analyze videos entitled "bum hunter." I analyze the bum hunter videos as part of simulacra, in which hyperreality is formed through simulation of videos found on YouTube (Baudrillard, 2006). It is possible that individuals who have viewed videos depicting violence against the homeless then take these views on as their own and then act upon them, either through acts of simulation or reality (Baudrillard, 2006; Mulvey, 1975). Such videos situate homeless individuals as creatures that need to be controlled or contained due to the labels placed on them by society and are easy to find and to prey on due to their marginal status as well as their spatial location. 


\section{CHAPTER II}

\section{LITERATURE REIVEW}

\section{The Homeless}

Homelessness is a physical lack of shelter as well as a label imposed upon people experiencing the lack of a permanent and stable shelter (Katz, 1989). The Stewart B. McKinney Assistance Act defines homelessness as "one who lacks a fixed permanent residence or whose nighttime residence is a temporary shelter, welfare hotel, or any public or private place not designed as sleeping accommodations for human beings" (Institute of Medicine, 1988: 137). The Stewart B. McKinney Homeless Assistance Act was signed into law by President Reagan in 1987 and was created to provide services to homeless individuals (Blau, 1992; HUD, 2007). The act combined almost twenty needs of the homeless into one act; however, it has been routinely underfunded (Blau, 1992).

Since the late $1970 \mathrm{~s}$, homelessness has become much more visible, because there are more Americans living on the streets than in the past (Blau, 1992; Jencks, 1994). This is because the number of individuals experiencing homelessness increased (Jencks, 1994) but also due to the shrinkage of skid rows (Shlay \& Rossi, 1992). Before this period, a large number of homeless individuals lived in skid rows, locations with affordable single room occupancy hotels, which were then torn down or rehabilitated into more profitable real estate (Jencks, 1994). 


\section{Issues of Homelessness}

Situations of homelessness consist of issues of situational factors as well as a product of the social structure in which they reside. Structural factors are those that are difficult for an individual to control, the demands of the labor market, the cost of affordable housing, and changes in welfare policy. Common characteristics that are associated with the homeless are mental illness and problems with substance abuse. While mental illness and substance abuse are seemingly popular issues within the homeless population, it is difficult to determine whether these are the causes or consequences of homelessness.

While many issues addressed in this section have been tied to increases in homelessness, the causal link is not as direct as it may seem (Jencks, 1994). How an individual reacts to the social circumstances they find themselves in varies. Jencks (1994) explains that if we knew the precise impact of social and personal issues that influence an individual's likelihood for becoming homeless a "vulnerability index" could be created, however no such measure exists. While scholars can point to causal factors that can be more likely to affect one group more than another, no two people in poverty are exactly alike.

\section{The War on Poverty}

With the War on Poverty in the 1960s, large amounts of federal grants were used to expand welfare programs to the needy (Katz, 1989; Miller, 1991). The War on Poverty was fueled by the belief that inequality was a result of unequal opportunities; the belief was that by powering individuals, poverty could be eliminated (Katz, 1989; Miller, 1991). In the process, the Office of Economic Opportunity (OEO) was created, which 
focused on juvenile delinquency, civil rights, job training, and education (Katz, 1989). While this initiative did reduce poverty, it also became clear that poverty was much more complex than simply limited opportunities (Miller, 1991). However, due to deindustrialization, the kinds of jobs that individuals were being trained for were becoming less available as the labor market moved into a dual labor market economy (Miller, 1991).

\section{Deindustrialization and Non-Standard Employment}

Deindustrialization began in the United States in the 1970s and 1980s when many of the nation's companies moved their manufacturing to countries where labor was cheaper, leaving low-skill American workers to work service sector jobs in the secondary labor market (Bluestone \& Harrison, 1982; Flynn, 2003). Between 1979 and 1984, 11.5 million workers lost their jobs because of deindustrialization, in which plants shut down or relocated (Blau, 1992). Those workers who were able to keep their jobs saw a drop in wages. For example, in 1973, 20 percent of workers entering the workforce earned less than $\$ 11,103$ and between 1979 and 1986 the number of workers earning less than $\$ 11,103$ rose to 36 percent (Blau, 1992). In addition, hourly wage rates show that the median wage in 1973 was $\$ 8.52$ and by 1990 , the median wage dropped to $\$ 7.46$ (Blau, 1992). In the current service economy, an individual needs some sort of advanced education to be competitive (Blau, 1992). These conditions have a polarizing effect, which has created a larger population of poor individuals, a shrinking middle class, and small upper class that holds much of the society's wealth (Blau, 1992).

In a dual labor market economy, standard jobs make up the primary labor market and non-standard jobs make up the secondary labor market (Sweet \& Meiksins, 2008). 
Nonstandard employment includes jobs that are part-time, day labor, on-call work, work attained through temporary-help agencies, or self-employment. Nonstandard employment is associated with unfavorable characteristics, meaning they are less secure, less likely to unionize, are less skilled, and pay less (Kalleberg, Reskin, \& Hudson, 2000). In addition, women, teenagers, minorities, and the poor are more likely to hold such jobs within the secondary labor market (Kelso, 1994). "Thus, employment in nonstandard work arrangements exposes workers to significantly worse jobs than does employment in standard full-time jobs, net of worker's age, education, occupation, and industry" (Kalleberg, Reskin, \& Hudson, 2000: 270).

Nonstandard workers are also more likely to move from job to job, making their employment history look less credible, which makes it even less likely for the worker to transition into the primary labor market (Sweet \& Meiksins, 2008). "[T]hese work and employment arrangements, much as they may offer opportunity to some, in fact deepen the inequalities within the American workforce and further the decline of opportunities for most" (Smith, 1998: 426). There has been a decline in job security and in jobs with standard employment practices. This has largely occurred because the tactics used for organizing work has largely been associated with the desires of the owners and not the needs of the workers (Sweet \& Meiksins, 2008; Kalleberg, Reskin, \& Hudson, 2000).

In the past, unions had blocked changes that were not in the favor of the employee; however, unions today are not as prevalent and thus not as effective (Blau, 1992). Such actions kept the employees relative wages down, making it more difficult to make ends meet (Blau, 1992). Through the decreases in wages in the service sector, workers were being compensated less and less, making it harder to survive. The principle 
of less eligibility contributed to the decline in funding for public assistance programs, which dictates that public assistance should provide less income than the working poor achieve to provide a disincentive for non-work. Because of the decrease in wages for the working poor, public assistance had to be cut to keep low wageworkers engaged in the workforce (Blau, 1992).

\section{Cost of Housing}

Throughout the 1970s and 1980s, the cost of rent rose higher than the poor were able to pay, which left many without housing (Rossi, 1989; Jencks, 1994). While the price of rent may not have increased by much in constant dollars, the percentage of total income needed to pay rent became much more substantial, which is referred to as 'rent burden' (Jencks, 1994). Even though there was affordable housing available through private and public providers, such locations were so unattractive and of such poor quality that people were willing to pay more than they could afford for a better dwelling (Blau, 1992; Jencks 1994).

\section{Welfare Reform}

During Reagan's presidency, efforts were taken to decrease all forms of social support, mainly Aid to Families with Dependent Children (AFDC) (Blau, 1992). AFDC was created in 1935 and was referred to as widow's aide or mother's aid, due to the decreased economic opportunities available for a single mother to support her children (Sernau, 2006). The Family Support Act required those receiving public aid to attain education or job training and automatic deductions were taken for child support from absent fathers. While such measures would seem to help individuals better themselves and their situations, what is not taken in to account is the inability of many of the 
handicapped and mentally ill to participate in the workforce, which the resulted in such individuals becoming homeless (Blau, 1992). In addition, many of the absent fathers whose children are on AFDC are also poor, subsequently making life more difficult for them as well (Blau, 1992).

The Personal Responsibility and Work Opportunity Reconciliation Act, created in 1996, changed welfare from the AFDC system to Temporary Assistance for Needy Families (TANF). This change limited the amount of time an individual could receive welfare benefits to a total of five years over a lifetime in periods no longer than two years. Through this act, block grants were given to each state, so they could choose how to dispense the funds. This reform was meant to rid poor people's dependence on welfare, but what it failed to do is give people in poverty marketable skills, realize that not all poor people are capable of work due to mental or physical disabilities, and fully address the problems of long-term welfare recipients (Sernau, 2006; Stricker, 2007).

\section{Working but Poor}

While there are benefits in place to aid the working poor, they do not enable a person to be upwardly mobile. Even if an individual is working, they still may not make enough to be able to afford housing (Ehrenreich, 2001). A 2006 report by the U.S. Conference of mayors indicates that 16 percent of homeless individuals are employed (U.S. Mayor Newspaper, 2006). An individual receives benefits like childcare grants, health insurance, and food stamps according to their income, but when their income increases, their benefits decrease. "In effect, increases in earnings are "taxed away" by lower benefit amounts" (Romich, Simmelink, \& Holt, 2007: 418). In some instances, individuals may find themselves worse off when they receive a raise. This type of 
taxation is referred to as implicit taxation, "situations in which part of the value of a worker's increased earnings is reduced by decreases in one or more means-tested benefits" (Romich, Simmelink, \& Holt, 2007: 419).

The way in which this system of benefits works does not easily aid the working poor to get out of poverty. Actually this stagnation of real income (either in-kind or job wages) could discourage work. "As a whole, this set of options does not allow workers to manage their own families' future in a way that gives a sense of control, rewards compliance with rules, or provides for increasing well-being" (Romich, Simmelink, \& Holt, 2007: 424). This system threatens increased earnings for a household and is likely to harm the households that rely on it most (Romich, Simmelink, \& Holt, 2007).

\section{Substance Abuse}

Many tend to believe that homelessness is caused by substance abuse; however, it is difficult to determine whether substance abuse is the cause or an effect of homelessness (Jencks, 1994). While surveys show that approximately one third of the homeless in the early 1980s had alcohol issues; "Advocates for the homeless usually argue that drug use, like mental illness is a product of homelessness" (Jencks, 1994: 43). On the other hand, conservatives tend to overemphasize mental illness and substance abuse as the main causes of homelessness (Blau, 1992).

\section{Mental Illness}

While there are individuals who are homeless that also have mental illness, this account describes a small proportion of the homeless. Approximately one third of the homeless have 'severe' mental disorders; however, hospitalizing these individuals would not reduce the impact of their illnesses (Jencks, 1994). "Diagnosing the homeless as 
mentally ill labels them as different and justifies their separation from society" (Blau, 1992: 77). Even though so few of the homeless have mental illness, "the psychological and the social symptoms of homelessness are hopelessly intertwined" (Blau, 1992: 86). Many blame deinstitutionalization of individuals with mental illness for a rise in the numbers of homeless individuals, but these accusations are not entirely correct. Deinstitutionalization did not occur as one large event, but as a series of events from the 1950s through the 1980s (Jencks, 1994; Blau, 1992). Prior to 1975, those released from mental institutions had social supports like Supplemental Security Income (SSI). In addition, severely mentally ill patients were held due to involuntary commitment; however, once involuntary commitment was disbanded, individuals who were not volunteering to leave were forced out due to budget constraints and left without any community support (Jencks, 1994; Blau, 1992).

With issues such as mental illness and substance abuse among the homeless, it is difficult to determine whether these characteristics are a cause or a consequence of an individual living on the street. However, both conditions make it difficult to maintain stable housing and work conditions (Elliott \& Krivo, 1991). Moreover, assumptions should not be made that suggest that those who are mentally ill or who have addiction problems will become homeless or that once an individual is homeless that these situations will likely ensue.

\section{The Protestant Work Ethic and Views of the Poor}

Many Americans do not truly understand what it is like to be in poverty and because of this, do not view poverty as a serious societal problem. When viewing homelessness, people have a tendency to blame the victim, by attributing the reasons that 
a person is homeless to personal problems the individual created that led to their current situation. "One significant reason is the inability to relate, and it turn understand, what it is to live in poverty and why people seem to be stuck there" (Segal, 2007: 334).

The stigmatization of the poor is not a new occurrence; in fact, records show that it goes as far back as the middle ages (Spicker, 1984). Laws and policies were created to stigmatize the poor by blaming the individual for their situation. More recently, ill treatment of the poor is less harsh; however, public opinion still blames individuals for their situation by connecting their status to bad behaviors and ill money management (Kluegel, 1987; Shapiro et al., 1987; Smith, 1987). In the past few decades, it has become increasingly difficult to interpret public opinions of the poor (Phelan, et al., 1997; Weaver, et al., 1995). Robinson (2009: 493) summarizes the findings from previous research regarding views of the poor:

1. Nationally, Americans consistently cast more individualistic than structural attributions towards the generic poor; 2. Although Americans attribute more individualistically than structurally, they admit the possibility of structural causes for generic poverty-often holding a mixture of beliefs instead of purely individualistic or structural ones; 3 . Regionally and locally, some populations may hold predominantly structural explanations for poverty, contrary to findings at the national level; and 4. Americans may hold different causal attributions for different subgroups of the poor.

(Robinson, 2009: 493)

The Elizabethan poor laws of the late 1800 s, influenced the way poor people were categorized in the United States (Katz, 1989; Wachholz, 2005). This view put poor people who were outside of a person's family into two categories: neighbors and strangers. It was only a person's responsibility to help their neighbors and strangers were 
not to be helped. Strangers were shipped back to their hometown to be cared for, even though this process could be costly (Katz, 1989; 1996).

In a report on the poor laws of the Commonwealth of Massachusetts by Josiah Quincy in 1821, he categorized the poor into two categories: the impotent poor and the able poor (Katz, 1989). The impotent poor are those who are unable to care for themselves due to disability, old age, infancy, and sickness, while the able poor are those who are physically able to work but chose not to for various reasons (Katz, 1989; Miller, 1991). Those who were able to work, but chose not to, were deemed immoral (Miller, 1991).

Also in Quincy's report, he distinguished the difference between people in poverty into the poor and paupers. Paupers were stigmatized because they received public relief and were believed to have chosen this position in society, whereas the poor were not stigmatized (Katz, 1989). However, making pauperism a moral issue stigmatized all people living in poverty. "Despite the effort to maintain fine distinctions [between the poor and paupers], increasingly poverty itself became not the natural result of misfortune, but the willful result of indolence and vice" (Katz, 1989: 13-14). This view of the impoverished moved right along into the early 1900s in America in conjunction with the birth capitalism and industry. This view of the poor justified their ill treatment and guaranteed that there would always be steady supply of exploitable workers (Katz, 1989; Miller, 1991).

Those who were successful in the market were held in high regards and personal worth, whereas those who were not successful were seen as moral failures. Although many people were in poverty, public policy did not come to the aid of the poor because it 
was seen as a moral issue; this view lasted even through the Great Depression (Katz, 1989). Due to the social stigma and even though people were unemployed, they were very hesitant to take public relief from the government, as "asking for relief became a sign of individual failure" (Katz, 1989: 16).

Americans have a strong sense of individuality, that all a person has to do is work hard and they will succeed. Middle-class status has been linked closely with individualism because it represents attaining economic rewards and moving up the ladder of success (Bellah, et al., 1985). Robinson (2009) has summarized the ideology of individualism (Feagin, 1972; 1975) in terms of Huber and Form's (1973) logic of opportunity syllogism, which explains how individualist ideology operates within American society:

1. Hard work in competition with others is valued.

2. Success through hard work in competition with others should be rewarded materially and nonmaterially (lack of success, on the other hand, should be denied such rewards)

3. Opportunities for success are available to all.

4. Because opportunities for success are available to all, the ability to be successful or to fail at being successful rests entirely upon the individual-personal effort, character traits, abilities, etc.

5. The existing social stratification system is a result of people being rewarded differently for their efforts based upon their personal ability to succeed within an environment of unbridled opportunity.

6. Because of the existing social stratification system results from individual effort, traits, abilities, etc., an individual's position within that stratification system is his or her responsibility; therefore, he or she is the only person who can effect a change in their position within the existing social stratification system.

(Robinson, 2009: 495-6) 
This viewpoint stems from what Weber (1905) defined as the Protestant work ethic, in which hard work pleased God and secured an individual's place in heaven. Over time, the religious link between hard work and going to heaven faded in its importance; however, the ethos of hard work remained (Hudson \& Coukos, 2005). "While Puritans worked to prove to themselves and others that they were God's elect, we now work with the same sense of moral obligation, but without explicit religious sanctions" (Hudson \& Coukos, 2005: 3). Hudson and Coukos (2005) argue that the Protestant work ethic affects the way American society views wealth and poverty. It is also because of this viewpoint that many believe that those who are homeless have created the situation for themselves; homelessness is seen as a threat to the current social order and to capitalism (Miller, 2000).

Views of the Homeless

The stigma that the homeless receive is even greater than that of poverty because homelessness is more visible to the public and "more disruptive than other forms of poverty; because of the difficulties involved in cleaning and grooming themselves, many homeless people also may be aesthetically unappealing" (Phelan, et al., 1997:325, italics in original). Many Americans assume that panhandling is central to homelessness, which many may be critical of because panhandling goes against the highly valued notion of work ethic (Lee \& Farrell, 2003). Panhandling is one aspect that is representative of homelessness for many Americans and induces many different emotions, ranging from sadness to anger. Panhandlers are predominantly male, more likely to never have been married, or have dependents. Substance abuse, mental health issues, experience with crime (as both victim and perpetrator), and participating in other subsistence activities are 
common among panhandlers. In addition, panhandlers tend to be homeless for longer periods than non-panhandling homeless persons (Lee \& Farrell, 2003). Because panhandlers are more visible to the public than other homeless persons, this image is assumed representative of all homeless individuals as compared to individuals who live in shelter, cars, or other temporary shelters.

In a nationally representative study by Phelan and colleagues (1997), a vignette was read to the participants and wording was slightly altered to convey that the man in it is either domiciled or homeless and sought medical treatment for mental illness or a back injury. Respondents viewed the homeless individual more negatively and more stigmatized than the poor individual. When the individual in the vignette was portrayed as homeless, respondents conveyed significantly greater social distance than when the individual was portrayed as living in a single-room apartment. In addition, labeling the individual as mentally ill makes them seem more dangerous, but also illicit a more empathetic response. When the individual was portrayed as having received treatment from a mental hospital, respondents conveyed a greater sense of dangerousness and were in greater support of economic aid than when the individual received treatment for back pain.

Nearly 60 percent of respondents, all from Nashville, Tennessee, in Lee, Jones, and Lewis's (1990) study connected homelessness with its structural causes and the remaining 40 percent of respondents placing blame on the individual. Approximately 90 percent of the respondents listed more than one cause that contributes to homelessness. Respondents who were liberal, black, from outside the South were more likely to reply that structural factors were the major cause of homelessness. Individuals who were 
highly religious were likely to see homelessness as an individual problem. Persons who had reported being 'panhandled' were more likely to see homelessness as a personal choice, whereas individuals who reported having conversations with homeless persons were less likely to have this viewpoint. Policy viewpoints were assessed by asking respondents which of four issues (crime, urban growth, the schools, traffic) were the most, less, or equally as important as homelessness. Respondents who believed in the structural causes of homelessness viewed few issues more important than homelessness; conversely, those who attributed causes of homelessness to individual characteristics were more likely to value issues other than those of the homeless.

Thompsett et al. (2006) found that younger and female respondents were more likely to be sympathetic towards the homeless and more conscious of the structural factors. Consistent with previous findings, liberals were also found to be more supportive of federal spending for homeless initiatives, greater compassion, and better understanding about the structural causes of homelessness. Conservatives reported being more concerned about national defense and reducing the deficit. African Americans were found to be more socially conscious and more liberal leaning, but also conveyed beliefs in common stereotypes of the homeless (mentally ill, having children, substance abusers). Individuals with higher education were more likely to view homelessness as a personal issue but did not buy into stereotypes of the homeless. In addition, those with higher levels of education were also more likely to give to panhandlers and support increased taxes to fund programs for the homeless. 


\section{Contact Hypothesis}

Lee, Farrell, and Link (2004) found that respondents in their national study who had greater exposure to persons experiencing homelessness were more likely to link homelessness with its structural factors. Regardless of what specific type of exposure an individual incurs, increased exposure positively influences sympathy towards the homeless (Lee, et al., 2004), verifying the contact hypothesis (Williams, 1947). Lee and colleagues defined exposure as the gaining of knowledge (through television, reading, and discussing), observation, interaction, and membership. Through increased exposure, individuals go through the process of simple learning, in which exposure provides new information for dominant group members, which then reduces the need to use stereotypes (Lee, et al., 2004). In addition, Farrell (2005) found that nationally, residents of disadvantaged, transitional spaces, where homeless persons are likely to be found, the presence of homeless individuals in a neighborhood is not a predictor of disorder.

\section{Criminalizing Homelessness}

Because of the rise in numbers of persons experiencing homelessness, which in turn makes them more visible to the public, communities are working to restrict access that homeless individuals have to public spaces (Amster, 2003; Wachholz, 2005). There are many community and governmental efforts taken to hide the homelessness problem in the United States (Blau, 1992). The homeless are seen as a symptom of societal disorder, threatening and criminal in nature; because of these beliefs, efforts are taken to remove them from sight. When society fears the homeless, any interactions with the population could provoke fear or the threat of danger, which causes the creation of criminalizing laws and ordinances. "Homeless persons embody the social fear of privileged 
consumers, fear for their families, for their children, fear that 'those' people will harm them and therefore must be placed as far away as possible from safe neighborhoods" (Wright, 2000: 27). Because of this societal viewpoint, the homeless are viewed and stigmatized in the this way; the police and others who seek to maintain order place close watch over the homeless which then increases the likelihood of arrest and criminalization (Barak \& Bohm, 1989; Snow, Baker, \& Anderson, 1989).

Hodulik (2001) describes ordinances such as those that prohibit aggressive solicitation and panhandling as "merely a band-aid solution to the more complex social and economic issues that force increasing numbers of Americans into the streets" (p. 1073). Those who oppose such ordinances felt that are an attempt to keep the poor out of the city and cater to the needs of the wealthy. Those who typically are against panhandling are those with downtown businesses and government officials, who are not necessarily representing the concerns of their constituents (Lee \& Farrell, 2003). Those in law enforcement, the court system, and others within the criminal justice system do not see regulating panhandling as a reasonable action. Rather, regulating panhandling is costly, does not solve the root causes, takes up a large amount of time, and does not deter recidivism (Goldstein, 1993; Simon, 1996).

Within the "broken windows" thesis, homeless individuals are viewed as indicators of disorder as well as litter, graffiti, loiterers, and strangers (Wilson, \& Kelling, 1982). Disorder then makes residents fearful, which in return weakens social controls because individuals avoid one another and stay behind locked doors (Wilson \& Kelling, 1982). Through this type of policing, the police and others who seek to maintain order 
place close watch over the homeless, which then increases the likelihood of arrest and criminalization (Barak \& Bohm, 1989; Snow, Baker, \& Anderson, 1989).

\section{Anti-Homeless Laws}

Many cities across the nation have criminalized aspects of homelessness by creating laws that prohibit loitering, panhandling, sleeping outside, as well as other aspects. The National Law Center on Homelessness \& Poverty (NLCHP) found between 1999 and 2001, out of the 49 cities surveyed, 70\% showed an increase in anti-homeless laws (NLCHP, 2002). If this continues, the homeless will face even more blocked access to the work force and to social services. For example, in Ventura, California, the city and service providers have teamed up to ensure that "nuisance offenders"- those who are charged with aggressive panhandling, public urination, and public intoxication-are refused social services (NCH \& NLCHP, 2006). This action makes it even more difficult for homeless individuals to gain jobs because they are not only criminal offenders due to the changing laws, but they do not have any means of social support.

Criminalization of homelessness is "the practices of local jurisdictions in legislating against basic life-sustaining activities such as sleeping, sitting, or storing personal belongings in places where people are forced to exist without shelter" (NLCHP, 2002: 3). Criminalization also consists of "the selective enforcement of other laws like loitering or public intoxication" against those experiencing homelessness (NLCHP, 2002: 3). These actions and policies not only place bans or limitations on everyday aspects of a homeless person's day but also criminalize their existence (Ferrell, 2001; NLCHP, 2002). Laws are enforced by police officers patrolling the streets or by making public spaces 
unfriendly to those homeless individuals who seek to use them. For example, park benches are modified, making them usable only for sitting, not sleeping.

\section{Crimes of the Homeless}

While the homeless do have an overall higher arrest rate, the causes of arrest are typically non-violent and are a result of their homeless status (Snow, Baker, \& Anderson, 1989). The types of offenses that the homeless are most commonly charged with are public intoxication, theft, violation of city ordinances, and burglary (Bauman, et al., 1985; Robertson, et al., 1985; Snow, et al., 1989). Snow and colleagues (1989) sampled homeless men with criminal records in a Southwestern city, and found that just over one percent of the homeless men were charged with violent crimes (part one crimes; murder, rape, robbery, and assault). Twenty percent of the homeless men were charged with property crimes (burglary, larceny-theft, and auto theft) and the remaining, nearly 80 percent were non-violent crimes (part two crimes). The Uniform Crime Report (UCR) measures crimes nation-wide and focuses on traditional forms of crime, called index crimes. The UCR measures homicide, forcible rape, robbery, aggravated assault, burglary, theft, and motor vehicle theft. Of the part two crimes, nearly 50 percent were substance related, while the other 30 percent were comprised of violation of city ordinances ( 8 percent), simple assault ( 4 percent), trespassing ( 3 percent), traffic warrants ( 3 percent), disorderly conduct ( 3 percent), and other minor offenses ( 7 percent). However, Fischer and colleagues (2008) emphasize that homelessness should be viewed by law enforcement as a situation which may cause individuals to act in ways that promote survival that may be illegal, rather than viewing homeless persons as criminals. In addition, homeless individuals with mental illness are even more likely to be 
criminalized because likely to exhibit symptoms of their disease, making them the most visible of those who are homeless (Belchner, 1989; Snow, et al., 1989).

Seemingly, simple activities for a non-homeless individual can turn into legal matters for the homeless. For example, if a homeless individual wants to enjoy an alcoholic beverage, they are usually unable to do so in a way that a person who is housed can. According to Snow (1989) and colleagues, nearly 50 percent of the arrests for all homeless persons in Austin, Texas during the time of their study were for public intoxication. Homeless individuals are typically unable to be able to afford a drink in a bar and are unable to drink in private because of their lack of housing (Snow, et al., 1989).

Exposure and Criminality among Homeless Persons

Fischer and colleagues (2008) found that among sheltered and unsheltered homeless persons, those who are sheltered are more likely to commit a violent crime as compared to unsheltered individuals. They attribute this to the close quarters that homeless individuals are subject to within the temporary shelter system and the heightened levels of stress that come from the homeless status. Once homeless individuals attain shelter that is more permanent, the likelihood of violence recedes. Fischer and colleagues (2008) explain, "These findings suggest that homeless individuals are not inherently violent, but that some become violent when exposed to temporary living situations such as shelters" (p. 262).

Homeless individuals who have spent long periods on the street are also at greater risk of criminalization (Snow, et al., 1989). This is because they are more likely to have lost personal identification, and less likely to have the means to achieve personal hygiene 
or to achieve stable employment. Those who have spent a longer amount of time on the street are also more likely to grab the attention of the police through their survival strategies, which are ways of acquiring goods or money through non-traditional means. These strategies are used either because they are unable to attain access to the formal economy or unable to survive on low wages that the formal economy provides. The informal economy provides opportunities for a whole host of jobs that are traditionally frowned upon by the dominant society. Wage earning activities in the informal economy include, but are not limited to, selling and trading salvaged items, selling illegal services and goods (e.g. drug dealing, prostitution), stealing, selling blood, scavenging, and panhandling (Fischer, Shinn, Shrout, \& Tsemberis, 2008; Snow, et al., 1989; Snow \& Anderson, 1993).

\section{Victimization of the Homeless}

While some homeless individuals may look threatening or dangerous, in reality they are not a serious threat, but are actually the victims of crime more than they are the perpetrators. The homeless face higher rates of victimization than domiciled individuals (Fitzpatrick, La Gory, \& Ritchey, 1993; Kushel, Evans, Perry, Robertson, \& Moss, 2003; Lee \& Schreck, 2005; Perron, Alexander-Eitzman, Gillespie, \& Pollio, 2008). Snow and colleagues (1989) found that homeless individuals were actually twelve times more likely to be victimized than non-homeless individuals were. This is partly due to the lifestyle that the homeless have, frequenting dangerous places or participating in hazardous activities makes them closer to possible offenders, making them vulnerable to victimization (Gaetz, 2004). The homeless are likely to become victims of individuals looking for vulnerable persons to assault, those that provide services to the homeless at 
inflated prices, those who underpay the homeless for the contracted work they provide, and to other homeless individuals (Lee \& Schreck, 2005). Many victimize the homeless because they are afraid of or hate the homeless, blame the homeless for their situation or do so as a way to convey that they do not belong in that area (Swanson, 2001; Wachholz, 2005; Wachholz \& Mullaly, 1993).

In a study by Lee and Schreck (2005), it was found that 54 percent of homeless individuals have been victimized in some way while living on the streets. Of the homeless individuals who were victimized, 34 percent were violently victimized and the remaining 64 percent were victimized through theft (Lee \& Schreck, 2005). Homeless men are more likely to be victimized than are homeless women and black individuals are more likely to be victimized than white individuals (Lee \& Schreck, 2005). Homeless women are more likely to be victimized by someone they know, rather than a stranger (Breton \& Bunston, 1992; Fisher, Hovell, Hofsterrer, \& Hough, 1995; Wenzel et al., 2001). In addition, homeless women are two to four times more likely to be victimized than housed women with similar socioeconomic status (Jasinski, Wesley, Mustaine, \& Wright, 2003; Perron, et al., 2008).

According to the 2007 National Crime Victimization Survey (NCVS), individuals in the general population who experience violent crimes most frequently are younger, black, poor, males (Rand, 2007) which is also consistent with victims of violent crimes who are homeless (Lee \& Schreck, 2005). Violent crimes are underreported to the police, and according to the NCVS, in 2007, only 46 percent of violent crimes were reported, as well as 42 percent of simple assaults were reported (Rand, 2008). Homeless individuals who have been victims of crime may expect that when they do report 
incidents of victimization, they will not be taken seriously, which could mean that reports are lower than reality or that if reported, the victim may fear retaliation from the offender (Lee \& Schreck, 2005; Ruback \& Thompson, 2001; Wardhaugh, 2000).

\section{Predictors of Victimization for the Homeless}

With many homeless victims of crime, victimization often times begins in childhood as victims of emotional, sexual, and/or physical abuse (Dietz \& Wright, 2005; Lee \& Schreck, 2005; Wenzel, Leake, \& Gelberg, 2001). Traumatic events such as these can lead individuals towards social exclusion, because the individual cuts off their current relationships and ties to institutions (Lee \& Schreck, 2005). Social exclusion makes a homeless individual more susceptible to victimization because of the weak ties they have to shelter, employment opportunities, and limitations on the usage of public spaces. These situations complicate their relationships with the police, which leave them with little access to safety from victimization (Gaetz, 2004; Lee \& Schreck, 2005).

In addition, homeless individuals that have chronic health conditions, mental illness, substance abuse, prostitution, and who beg or panhandle are also more likely to be victimized (Baumohl \& Miller, 1984; Lee \& Schreck, 2005; Whitbeck \& Simons, 1993). Victimization can also lead to homeless individuals abusing drugs or alcohol in the future as a way of coping with their victimization (Kilpatric, Acierno, Resuick, Sanders, \& Best, 1997; Wenzel et al., 2001). Victimization can also create or worsen mental health issues (Kilpatrick \& Acierno, 2003; Sorenson \& Golding, 1990). Isolation and Victimization among Homeless Persons

Rossi (1989) found that the average homeless person does not keep in close contact with relatives and does not have well-built friendships. "Being without secure 
shelter has a profound impact on a person's ability to exert greater control over her life to develop a lifestyle that allows her to eat and sleep with greater consistency, be healthy, and maintain employment" (Gaetz, 2004: 429). Homeless persons are also victimized because of their weak social capital, leaving them without social contacts and relationships (Gaetz, 2004).. With only weak social ties, many of the homeless do not have individuals outside of the homeless community they can go to for support and resources (Gaetz, 2004; Lee \& Schreck, 2005).

Since the homeless are typically excluded from the formal economy, nontraditional ways of making money are used, which are typically unregulated or short term endeavors, while these activities provide income, they also make homeless individuals targets that are more valuable to perpetrators (Gaetz, 2004). Homeless individuals who earn some form of income legally through work or government checks are also more susceptible to crime, while those who earn an income illegally through activities like drug dealing are less likely to be victimized (Lee \& Schreck, 2005).

\section{Evidence of Violence against the Homeless}

The National Coalition for the Homeless $(\mathrm{NCH})$ produces a yearly report detailing hate crimes and violence against people experiencing homelessness. From 1999 to 2009 , the NCH has documented 880 violent acts throughout the United States and 244 deaths of people experiencing homelessness through violent acts against them. The majority of the victims since 1999 have been male (547) and their ages range from 4 months to 74 years old. In 2008,106 homeless people were violently assaulted and 27 people died as a result of being attacked $(\mathrm{NCH}, 2008 \mathrm{~b})$. 
Since 1999, approximately 244 homeless individuals have died due to attacks, whereas 94 individuals have died because of a hate crime due to race, color, religion, national origin, or sexual orientation, which illustrates the severity and intensity of attacks against homeless persons ( $\mathrm{NCH}, 2009$ : 32). Under current legislation, violent acts against the homeless are not considered hate crimes; however, efforts are being made by organizations like the $\mathrm{NCH}$ to classify such acts (see $\mathrm{NCH}$ report, 2009). "Hate crimes are discriminatory crimes where a substantial part of the motive is the actual or perceived status characteristic of another" $(\mathrm{NCH}, 2009: 35)$. Such a definition includes actions taken against the homeless whether or not official legislation defines acts as such.

[T]he perpetrators' characteristics, motive[s], and weaponry are very similar to perpetrators who commit hate crime[s] against all other hate crime victim groups. Regardless of whether the motive of the perpetrators was that of opportunity or of bias against homeless persons, homeless persons continue to remain particularly vulnerable victims due to the nature of homelessness.

( $\mathrm{NCH}, 2008 \mathrm{~b}: 10)$

The vast majority of attackers are white, male, middle class under the age of 25 (Mock, 2007; NCH 2008b). The perpetrators stated reasons for attacks against those experiencing homelessness were that they were bored, because the victim is homeless, just for the 'fun' of it, or just because they 'could' (NCH, 2008b: 10).

\section{The Link between Criminalization and Victimization of the Homeless}

Criminalization then situates the homeless as socially acceptable targets for some to take violent action. The executive director of the $\mathrm{NCH}$ stated, "It seems that disturbed violent people take a cue from their cities' responses to homelessness and become emboldened with more violent attacks if the city has portrayed homeless people as the cause of unemployment, decreasing property values, or vacant storefronts" $(\mathrm{NCH}, 2007$ : 
77). By regulating the homeless in public spaces, this often pushes the homeless from areas they can obtain greater safety into more dangerous areas, where they have less control over their environment, and this in turn increases the likelihood of criminal victimization (Gaetz, 2004). Additionally, the homeless can choose to move to marginal spaces in order to conceal their prohibited actions (e.g. sleeping and drinking) which again could put them at greater risk of being victimized (Duncan, 1983; Snow, et al., 1989). Overall, "Laws that criminalize the homeless encourage the belief that homeless persons are not human, are unworthy of respect, and attacks against the homeless will go unnoticed" (NCH, 2008b: 9). Such regulations, regardless of perceived or actual need to regulate the homeless population, work towards creating an environment that is structurally conducive for violent acts against the homeless.

Bum Fighting Videos

Starting in 2001, four videos were created and sold illustrating "bum fighting" in which homeless people were depicted fighting or performing stunts in return for alcohol and/or drugs (NCH, 2008b). Previous research on Bumfights videos focused on the first amendment rights of the film producers (Day, 2008) and how internet-fighting videos commodify violence and incentivize individuals to make their own videos (Slater, 2005). The vast majority of bum fighting videos fall in one of two categories: physical violence against the homeless and homeless people performing humiliating tasks (Moriarty, 2009). Four films have been created and distributed "Bumfights: Cause for Concern," "Bumfights 2" and "Bumfights 3: The Felony Footage" and "Bumfights 4: Return of the Ruckus." A legal agreement stipulates that no more copies can be legally created and distributed; however, pirated versions can be easily found on the internet (Perry, 2006). 
Over 6.8 million copies of the videos have been sold, but currently major retailers no longer sell the videos, however they can still be attained through smaller companies (NCH, 2009). Ryan McPherson is the creator of "Bumfights" and soon after the film came out, he and his three partners sold the film for $\$ 1.5$ million (60 Minutes, 2006). In addition to the videos, a bum-fighting website was also created. In early 2008 , the bumfighting website was shut down due to a civil lawsuit filed by the homeless individuals who were involved, which provided monetary compensation to the victims (NCH, 2009). Just because the website itself no longer exists, does not mean that such videos cannot be easily found on the internet. The NCH has found that on YouTube alone, there are 5,690 videos with the word "bum fights" in the title (NCH, 2009: 34).

Within the content of the original bum fighting videos, there is a segment where an individual, called the "bum hunter" stalks, captures, and studies homeless individuals as if he was on safari. In the process of bum hunting, he tags homeless individuals or returns them to their "natural habitat" (60 Minutes, 2006). From this segment, many individuals have simulated the bum hunter's actions, produced their own videos, and uploaded them to YouTube, viewing such actions as sport (60 Minutes, 2006; Malernee, 2006; Molloy, 2006). It is this specific segment and the simulation by copycats, spawned from the bum fighting films, which is the focus of my research.

\section{Link between Bum Fighting Videos and Victimization}

The NCH directly links the release of these videos to the increase of attacks against the homeless throughout the nation, many videotaping the ordeal, imitating the original videos. "These videos represent a new form of dehumanization and exploitation against homeless individuals" $(\mathrm{NCH}, 2008 \mathrm{~b}: 35)$. In the two years following the release 
of the Bum fights videos, the NCH has documented that violence against the homeless increased sixty-seven percent (Haas \& Malernee, 2006; NCH, 2008b). In addition, several attacks on homeless persons have been directly linked to the bum fight videos though police investigation (60 Minutes, 2006).

\section{Current Study}

I employ the cultural criminology perspective that emphasizes, "The placing of crime and its control in the context of culture; that is, viewing both crime and the agencies of control as cultural products - as creative constructs" (Hayward \& Young, 2004: 259). Cultural criminology emerged out of subcultural theory and labeling theory through the evaluation of exclusion and inclusion in society, questioning if exclusion was a matter of biology, intelligence, or cultural inadequacy that characterized exclusion (Ferrell, Hayward, \& Young, 2008). Orthodox criminology views obeying the rules as the path of mainstream culture and crime and deviance actions of those who are deficient of culture, which does not allow for criminal and deviant behavior to have cultural meaning (Ferrell, Hayward, \& Young, 2008). The cultural criminology perspective emphasizes "the creative characteristics of culture, and hence the human creation of deviance and the human creation of the systems attempting to control it" (Ferrell, Hayward, \& Young, 2008: 31). Through the lens of cultural criminology, we are able to view the cultural construction of homelessness as deviant, according to cultural values, which then criminalizes such characteristics. With such ordinances in place, the environment provides a structurally conducive atmosphere for actions against the homeless by those who see themselves as allies of such laws. 
I analyze the bum hunter videos from the larger group of bum fights videos as part of simulacra, in which hyperreality is formed through simulation of videos found on YouTube (Baudrillard, 2006). It is possible that individuals who have viewed videos depicting violence against the homeless then take these views on as their own and act upon them, either through acts of simulation or reality. Such videos further situate homeless individuals as creatures that need to be controlled or contained due to the labels placed on them by society and are easy to find and to prey on due to their marginal status in society as well as spatially.

Before I conducted my analysis of the bum hunting videos, several key questions guided my research. What types of violence are being used against homeless individuals? How severe is the violence against homeless individuals? What are the consequences and results of the violence against homeless individuals? Can patterns and themes of the assailants' neutralization, motivations, and intentions be identified within the videos displaying crimes against the homeless? Do the videos glamorize the violence portrayed against the homeless (i.e. is the hunter situated as the hero and the homeless individual the villain)? Is the violence against homeless persons made attractive for the viewer? Does the participatory culture of YouTube encourage such videos to be made?

\section{Conceptual and Theoretical Framework}

To understand the link between the criminalization and the victimization of the homeless and the rise in bum hunting videos found on YouTube, several key areas of interest need to be addressed. First, I will seek to understand the processes that label the homeless as deviants and indicators of social disorder and how such labels justify the actions taken against them. Secondly, I will seek to understand what it is about the 
homeless that makes them especially vulnerable to victimization by analyzing their marginal status in society, which in turn pushes homeless individuals into marginal spaces, where victimization is more likely to occur. In addition, I will use routine activities theory to better understand what it is about the lifestyle of homeless individuals that make them vulnerable to victimization. Finally, I will look at the participatory culture that surrounds interactive media usage and the role that media usage plays in encouraging participation through the uses and gratification hypothesis. By viewing media content in this way, bum hunting is situated in the realm of possible action to be taken against the homeless. Simulacra helps to emphasize that whether or not the videos uploaded to the internet are portraying an actual event or a simulated one, the message to the viewer is the same even if the viewer knows the event is simulated.

\section{Criminalization of the Homeless Framework}

\section{Minority Threat Hypothesis}

Deviance within a capitalist society is formed through an imbalance in power (Quinney, 1980). The homeless individuals are a subordinate group in society, which is seen as a threat to capitalism and to social order (Spitzer, 1975). Through criminalization, the homeless and other subordinate groups are controlled through legislation passed that outlaw actions of their specific subordinate group, which pose threats to the current economic order. As noted above, the $\mathrm{NCH}$ has seen a drastic increase in anti-homeless laws throughout the nation (NCH, 2002). Such laws protect the interests of the dominant group through the physical removal of homeless persons from desirable public places. Through this process, the homeless are labeled as deviants. 


\section{Labeling Theory}

Homeless individuals are also labeled as deviants because they are viewed to live outside of society's norms and values as persons that cannot manage money and do not value hard work. The homeless population is labeled in this way because American culture and the Protestant work ethic dictate that if you work hard, you will succeed and if you have not succeeded, then you have not worked hard (Weber, 1905). Homeless individuals whether they have committed a deviant act or not, are labeled as deviant because society views them as such (Becker, 1963).

\section{Stigma}

When interacting with others, one is able to present the self of their choice through a process Goffman (1959) defines as impression management. Through impression management, an individual performs a role in which they believe will be socially accepted by others (Goffman, 1959). Performances occur on the front stage, which is typically a fixed location; the personal front consists of items, which reinforce the individual's performed role. Appearance gives clues as to an individual's social status and manner provides information for the audience to formulate expectations of the performer. Through performances, roles become institutionalized, in which certain expectations are placed on different roles played (Goffman, 1959). When an individual is part of a stigmatized group like the homeless, his or her ability to convince others of the role presented is diminished and social acceptance is prevented (Gramlich, 2008). Even before interacting with the homeless, many have negative perceptions due to their stigmatized label (Raskin, Harasum, Mercuri, \& Widrick, 2008). 


\section{Broken Windows Thesis}

Within the broken windows thesis, homeless individuals are labeled as indicators of disorder, which are linked with crime (Wilson \& Kelling, 1982). If there is disorder in a neighborhood, crime is likely to follow if the necessary actions are not taken. Wilson and Kelling (1982) use the analogy that if there is a broken window in a building and it is not quickly repaired, soon all the windows will be broken; disorder will take over the neighborhood. While actual broken windows and homeless individuals in a neighborhood can be viewed as disorder, that is not the only indicator, other indicators are the presence of litter, graffiti, loiterers, and strangers (Wilson \& Kelling, 1982). Disorder then makes residents fearful, which in return weakens social controls (Wilson \& Kelling, 1982). Due to weakened social controls, individuals avoid one another and stay behind locked doors, regardless of whether or not crime actually increases (Gault \& Silver, 2008; Wilson \& Kelling, 1982). Taking care of these small indicators of social disorder should curtail the escalation of more serious crimes and examples of social disorder within the neighborhood (Wilson \& Kelling, 1982). By removing those individuals who are perceived to be homeless from an area, order is expected to be maintained.

Regulars in the neighborhood consist of decent folk who are law-abiding citizens who live within the neighborhood and local drunks who may be known within the community to be deviant but not criminal. Strangers to the neighborhood are viewed as potential criminals or troublemakers and are viewed by the neighborhood with suspicion. "This opposition of orderly and disorderly people cuts across a further pervasive insideroutsider dichotomy, in effect producing two categories of troublemakers-the disorderly 
insiders, who need to be controlled, and the disorderly outsiders, who need to be excluded" (Harcourt, 2001:25). There are two groups of deviants, the local drunks and the strangers; however, it is only the strangers who are viewed suspiciously as criminals because outsiders do not know the rules of the neighborhood, whereas the local drunk may be deviant but knows how to operate within the community.

\section{Moral Entrepreneurs}

Order is maintained in the neighborhood through police efforts and neighborhood organizations, such as neighborhood watches or community watchmen (Wilson \& Kelling, 1982). Police efforts consist of foot patrol tactics, using quality-of-life policing, which utilizes the broken windows theory by "eliminating visible disorders experienced by everyday annoyances for large numbers of urban residents as the key to reducing serious crime and restoring neighbourhoods" (Vitale, 2005: 100). It is necessary to eliminate all indications of disorder from a neighborhood; while one seemingly disorderly person may not cause harm, "failing to do anything about a score of drunks or a hundred vagrants may destroy an entire community" (Wilson \& Kelling, 1982: 5). Through this type of policing, an emphasis is made on creating or maintaining order by removing persons or objects that indicate disorder (panhandlers, trash, etc.). Community watchmen have much of the same effects as foot patrol officers, who "take the law into their own hands-without punishing persons or using force" (Wilson \& Kelling, 1982: 7).

Police officers and neighborhood watch organizations are not the only groups that patrol the streets; a third type of order enforcer is the vigilante. Vigilantes take the law into their own hands, "acting [as] judge, jury, and often executioner as well as 
policeman" (Wilson \& Kelling, 1982: 7). Vigilantes "don't take the law; they break the law" (Karmen, 1984: 248) by using force, without any of the limitations that a police officer would use (Becker, 1963; Karmen, 1984). Becker (1963) describes such individuals as moral entrepreneurs, who believe that their actions are correct and will benefit others, providing a better quality of life to the community. "Led by individuals from the local power elite, with a solid middle-class membership, vigilance committees singled out people at the bottom of the social hierarchy for [physical] attack" (Karmen, 1984: 249). In their own eyes, vigilantes and moral entrepreneurs view themselves to be true patriots and as individuals who uphold the moral codes of society (Becker, 1963; Karmen, 1984).

Neighborhoods in which windows are quickly repaired are filled with "windowlovers" (Wilson \& Kelling, 1982). In these neighborhoods, individuals work quickly to fix the broken window, displace the panhandlers, clean up the litter, and curtail loitering because they believe that it is unlikely that crime will occur in an orderly neighborhood. By maintaining order, through informal social control, crime is to be curtailed, which also reinforces attachment of community members the neighborhood (Wilson \& Kelling, 1982). Quality of life policing by police officers, community watchmen, and vigilantes all use informal social control to deter crime and disorder by utilizing mediation and intervention (Burchfield, 2009).

In neighborhoods where broken windows go unattended, informal social control is low, and this gives the perception that no one cares. When no one cares about the neighborhood, there is not likely that order and community controls can be maintained. While it is not certain that crime will take over the neighborhood, residents view the 
possibility as reality. In this process, community members change many of their habits, like walking in the neighborhood at night or they tend stay in their homes more often, which inevitably adds to breakdown of order in the neighborhood (Hale, 1996; Vitale, 2005; Wilson \& Kelling, 1982).

\section{Victimization of the Homeless Framework}

Through the dichotomy of regulars and strangers, rationalizations are made in order to justify the perpetrator's actions towards the strangers, the perceived cause of social disorder. In the case of the homeless, they are not seen as victims, but rather their ill treatment is punishment for their deviant status. Victimization of the homeless, through this form of neutralization, would imply that they are a group that is made up of appropriate targets for deviant actions. Viewing their actions in this way, perpetrators neutralize their actions as serving justice and keeping groups of people in line (Sykes \& Matza, 1957). Neutralizations are rationalizations used when perpetrators view their actions, which insulate themselves from blame, placing it on someone else (Maruna \& Copes, 2005; Sykes \& Matza, 1957).

In addition to the denial of the victim, neutralization can also occur as the denial of injury, denial of responsibility, condemnation of the condemners, and the appeal to higher loyalties (Sykes \& Matza, 1957). Through neutralization, individuals justify or neutralize their actions taken against the homeless. Neutralization of deviant behavior can also occur through the denial of injury to the victim. In this way, the perpetrators believe that no harm has been done if no one has been injured; actions are viewed as the extension of norms, rather than the breaking of norms. Through denial of responsibility, a perpetrator claims that such deviant actions took place because of outside forces beyond 
his control, rather than through his own choices and actions. The condemnation of the condemners is neutralization through which the perpetrator of the deviant act reflects the focus back onto those individuals who criticize their actions. By doing so, the focus of attention has shifted from the condemned to the condemner, suppressing the actions of the deviant. The appeal to higher loyalties neutralizes deviant actions by claiming that such acts were committed for the good of smaller groups or friendships rather than the larger society. By neutralizing actions in this way, deviants hold some of the norms of society more closely than other norms, resulting in role conflict (Sykes \& Matza, 1957).

\section{Marginality}

Homeless individuals face high rates of victimization (Fischer, 1992; Fitzpatrick, LaGory, \& Ritchey, 1993; Lam \& Rosenbeck, 1998), which can be linked with their marginal status in society (Lee \& Schreck, 2005). Because of this marginal status, homeless persons are considered outsiders and are not fully accepted in society (Lee \& Schreck, 2005) this can also be viewed as the rejection of the civil, political, and social rights of the individual (Snow \& Anderson, 1993; Walker \& Walker, 1997). Marginality translates into decreased employment opportunities, weakened social capital, and limited access to public spaces (Gaetz, 2004).

Prime spaces are those made up of residential, commercial, and recreational areas used by domiciled individuals, corporations, and forms of government. Marginal spaces are those spaces, which are displeasing and invaluable for domiciled individuals, and are run down areas that consist of vacant buildings and homeless encampments (Duncan, 1983; Farrell, 2005; Snow \& Anderson, 1993; Snow \& Mulcahy, 2001). Marginal spaces are also socially disorganized, in that they exhibit three key structural factors, low 
economic status, ethnic heterogeneity, and residential mobility (Shaw \& McKay, 1942; Sampson \& Groves, 1989). Homeless individuals tend to reside in these areas because they are not useful for domiciled populations (Logan \& Molotch, 1987).

Transitional spaces are areas where the borders of prime and marginal spaces are blurred and where domiciled and homeless individuals come into contact (Snow \& Mulcahy, 2001). Such interactions occur in transitional spaces as well as prime spaces because it is in these areas that homeless individuals are likely to act upon survival strategies (i.e. panhandling, day laboring, scavenging) and find social services. Through interactions with the homeless population, domiciled individuals may feel apprehension and uncertainty (Snow \& Mulcahy, 2001) which could lead to poor treatment and victimization of homeless individuals.

\section{Routine Activities and Lifestyle-Exposure}

Both the routine activity patterns and the lifestyle of homeless individuals affect their likelihood of victimization, which explains certain circumstances in which crime is more likely to occur (Cohen \& Felson, 1979; Hindelang, Gottfredson, \& Garofalo, 1978). The routine activities theory explains that crime is more likely to occur when the three criteria are present at the same place and time. "Most criminal acts require the convergence in space and time of likely offenders, suitable targets, and the absence of capable guardians against crime" (Cohen \& Felson, 1979: 588). The lifestyle-exposure theory explains that an individual's daily activities and leisure activities may bring them in contact with crime. The marginal status of homeless individuals situates them as suitable targets, they are pushed from prime to marginal spaces, where motivated offenders are likely to be found, and where there is a lack of police protection. Since 
homeless persons do not have a fixed residence, an important aspect to preventing victimization (Meier \& Miethe, 1993), homeless persons must carry their possessions with them, which also increases the likelihood of victimization (Lee \& Schreck, 2005).

\section{Media Framework}

\section{Uses and Gratification}

YouTube was created in 2005 and within six months, was providing 60 percent of videos watched online (Haridakis \& Hanson, 2009). YouTube provides media content atwill, rather than through the rigid schedules of the television (Cha, et al. 2007). In addition, individuals can rate videos, post comments, and share links with others (Haridakis \& Hanson, 2009). Such an environment creates a participatory culture, which invites viewers to join or "Broadcast yourself," which is in fact the motto of YouTube (Burgess \& Green, 2009; Jenkins, 2006). The environment of YouTube is one in which "fans and other consumers are invited to actively participate in the creation and circulation of new content" which Jenkins defines as participatory culture (2006: 290).

Haridakis and Gary (2009) use audience-centered perspectives when studying such web content, focusing on the viewers' uses and gratifications of the media. This vantage point subscribes to the belief that media uses and effects are based upon an individual's goals and purpose. Rubin and colleagues (2003) summarize the assumptions for why and how individuals use media:

(a) Media behavior is purposive, goal-directed and motivated, (b) people select media content to satisfy their needs or desires, (c) social and psychological dispositions mediate that behavior and (d) the 'media compete with other forms of communication-or functional alternatives - such as interpersonal interaction for selection, attention, and use. 
(Rubin, et al. 2003: 129)

Through the viewing of media, the viewer identifies with the main character, in which the viewer internalizes and self-regulates according to that view (Mulvey, 1975). It is reasonable to suggest that individuals who watch bum hunting videos internalize the views displayed, and attempt to emulate the images presented, either through reality or through simulation.

\section{Simulacra and Simulation}

Simulacra are simulations of reality (Baudrillard, 2006), in which this new reality joins the realm with the original reality and becomes hyperreality. Once reality is established, it is open to interpretation and simulation, which creates hyper-realities. When hyperreality is created, it is nearly impossible to tell reality from hyperreality. This worldview cannot be viewed as an alteration of reality or as an outcome of the transmission of technology, but is an objective reality (Debord, 1994).

Baurillard (2006) gives an example of a simulated robbery, while to the person initiating this hyperreality it is only a simulation, but to everyone else it is perceived as reality. This also holds true for bum hunting videos; regardless of whether or not they are attacking real homeless persons, the videos are still portraying a reality in which the homeless are acceptable targets. Both simulations and reality are offensive. Not all videos on the internet are portraying actual 'bums' but rather the perpetrator's acquaintance; however, these videos are just as serious as those actually assaulting the homeless. These simulated videos still signify that a homeless person holds a deviant position in society and because of this label must be controlled. Even when videos are clearly simulation, it is still likely that such simulations still frame homeless individuals 
as structurally conducive targets of violence and harassment. Within this hyperreality, a link is made that connects the presence of the homeless with disorder. This reality is then broadcast to others through the transmission of media and creates "social relationship between people that is mediated by images" (Debord, 1994: 12). These videos then document for the viewer how to approach the homeless, what they are like, how they will react, and what to do if they fight back (Felluga, 2002). 


\section{CHAPTER III}

\section{METHODOLOGY}

Thousands of video clips have been uploaded to websites like YouTube, documenting violence against the homeless. Many of the perpetrators videotape themselves and from the videos, it is evident that they are actively searching for persons experiencing homelessness. They explain that they are searching for 'bums,' who can be lured like a fish to a worm with a beer or the prospect of drugs. The NCH (2008) states that the perpetrators enact violence against the homeless just for fun or because they are bored, I attempt to uncover additional underlying meanings to their actions. To achieve this, I specifically focus on videos pertaining to the "bum hunter." The "bum hunter" is an individual within the original bum fighting videos who stalks, captures, and studies homeless individuals as if he was on safari. In the process of bum hunting, he tags homeless individuals or returns them to their "natural habitat" (60 Minutes, 2006).

For my analysis of the bum hunting videos, I use ethnographic content analysis (Altheide, 1987). Ethnographic content analysis combines aspects of content analysis and the grounded theory approach in a way that a researcher may start with some coding categories, but remains flexible and adds emergent themes as they become apparent in the research process. Content analysis a process of data collection through which 
communication content is translated into numerical data according to a systematic set of rules (Paisley, 1969). Grounded theory is "a set of integrated conceptual hypotheses systematically generated to produce and inductive theory about a substantive area" (Glaser with Holton, 2004). Utilizing aspects of content analysis and grounded theory, ethnographic content analysis is methodical but not rigid, leaving room for new concepts to emerge from the data, as well as using the guidance of previously defined variables (Altheide, 1987). Data is collected in numerical form as well as narrative form, fluidly expanding to incorporate new discoveries. "ECA [ethnographic content analysis] is embedded in constant discovery and constant comparison of relevant situation, settings, styles, images, meanings and nuances" (Altheide, 1987: 68).

For the purposes of this research, YouTube will be the source from which the data is acquired. While YouTube is not the only website in which video content can be uploaded and viewed, Burgess and Green (2009) explain that because of its diverse content, status in Western, English speaking countries it is constructive for understanding "the evolving relationships between new media technologies, the creative industries, and the politics of popular culture" (p. vii). YouTube and other similar websites are online locations for users to upload and view their own and other individual's videos. These types of videos are known as user generated content, because they are largely generated by the people who use the website. Viewers are also able to comment on videos, which may serve as positive or negative reinforcement for such content.

A search on YouTube was conducted using the search term "bum hunter." The videos were sorted by YouTube according to relevance, collected on March 17, 2010, and numbered in accordance with the sequence they were downloaded. Videos were viewed, 
coded utilizing a coding scheme adapted from the work of Mustonen and Pulkkinen (1997) as well as transcribing the dialogue and actions.

\section{The Coding Scheme}

The coding scheme adapted from Mustonen and Pulkkinen (1997), was used in their analysis of television violence as well as by additional studies of media violence (such as example, Fernandez-Villanueva, et al., 2009; and example Mustonen, 1997). Violence is defined as "actions causing or designed to cause harm to oneself, or to another person, either physically or psychologically, including implicit threats, nonverbal behavior, and outbursts of anger directed towards animals, and inanimate objects" (Mustonen \& Pulkkinen, 1997: 173). Mustonen and Pulkkinen's (1997) coding scheme collects data on the prevalence, salience, and messages of the violence portrayed in media content (see Appendix A).

Prevalence of violence measures the frequency and type of violence demonstrated. The mode of the violence is coded in regards to whether it manifested itself in physical violence, verbal violence, or a combination of the two. Physical violence is coded as shooting, threatening, fist fighting, hitting with weapons, strangling, poisoning, stabbing, sexual violence, tying up, arresting, and damaging property. Use of verbal aggression was also coded for in categories that differentiated angry talk, use of stereotypes, mild personal insult, and serious threatening. Nonverbal psychological violence is coded as forcing, threatening, violating one's human rights (sexual violence, abuse, torture, detention), and scorning gestures.

Salience of violence is measured by evaluating the seriousness and intensity of the violence. The seriousness is documented by the realization of the violence as being 
playful, forcing, threatening, trying to insult, insulting, trying to kill, and killing. Consequences of the violence are coded as no consequences portrayed, no harm, only material harm, mild injuries, moderate injuries, severe injuries, and death. The intensity of the violence is a summative rating ranging from no violence to brutal violence (Mustonen \& Pulkkinen, 1997).

Messages of violence are measured and coded by evaluating the justification, dramatization, glamorization, efficacy, and attractiveness of the violence portrayed. Justifications of the violence are measured to garner greater understanding into the intentions of the aggressor, their perceived motivations, and whether or not the violence appears to be planned. The dramatization of the violence documents the length of the violent act and the clarity of the depiction of violence. In addition, dramatization codes for the type of atmosphere created through violence, whether it is neutral or unclear, humorous, quarrelsome, exciting, or frightening. The glamorization of the violence codes the nature of the aggressor and victim as villain, hero, animal, or neutral. Glamorization also measures the level or presence of audiovisual effects.

Efficacy of the violence codes the consequences of the violence as fully, partially, or not depicted. Examples of consequences of violence are suffering, injury, retaliation, and encounters with law enforcement. Efficacy of violence also codes the level of gratification that the aggressor demonstrates as having no gratification to complete gratification. The attractiveness of the violence is an overall rating of the level of attractiveness of the violence portrayed (Mustonen \& Pulkkinen, 1997). Attractive violence would be a violent act that depicted no suffering, no consequences, and complete gratification. 
For my analysis, in addition to using Mustonen and Pulkkinen's (1997) violence coding scheme, I drew upon concepts summarized in the review of literature as well as the theoretical framework to guide my analysis as well as emergent themes. While viewing each video I transcribed speech as well as actions. After viewing all videos, the text was coded and grouped into categories. The unit of analysis is video scene. Videos were broken into scenes if there was more than one interval of violence and/or if the video creator defined separate scenes within the video by using titles or fading, or cutting away to a different location.

\section{The Sample}

For my sample, I downloaded the first 100 videos that I was presented with using the search term "bum hunter" on YouTube's website. I numbered each video in numbered in accordance with the way in which the videos were displayed, according to YouTube's relevance ranking. In YouTube's search options, is not clear what makes one video more relevant than another video. The first 66 videos had the words "bum hunter" in the title. The remaining 38 videos had variations of bum, bum hunter, hunter, and bum patrol and five had no clear-cut relationship to the search term "bum hunter" in its title. The average length of the collected videos is two minutes and fifty-four seconds, with the longest being ten minutes and forty-two seconds and the shortest being thirteen seconds. The video that had been viewed the most had been watched 485,147 and was the video that was number one in the search results; however, there does not appear to be a

relationship between number of views and search result ranking $\left(R^{2}=-0.175, p>.05\right)$. The least viewed video had only been watched twelve times. The dates that the videos were uploaded to YouTube range from June 25, 2006 to March 3, 2010. 
I collected data on the first 40 videos from my search results; however, five were dropped from the sample because the content of the videos did not pertain to bum hunter, the homeless, or bum fights. The 35 remaining videos were broken into scenes if there was more than one completed act of violence and/or if the video creator defined separate scenes within the video by using titles or fading, or cutting away to a different location, resulting in 57 analyzed scenes. After viewing forty videos, I felt the data was saturated and coded the written transcripts with emergent themes (Glaser \& Strauss, 1967; Altheide, 1987). The upload dates, length of video, as well as number of views were documented for each video. Notes were taken documenting the actions and the dialogue from all 57 scenes from the 35 remaining videos in the sample. I read over my notes and coded for emergent themes, which were then extracted and placed into themes (Altheide, 1996; Glaser \& Strauss, 1967). 


\section{CHAPTER IV}

\section{FINDINGS}

Analysis of the Bum Hunter Videos

Within the sample were clips that appeared to be from the actual bum fighting videos, which were produced and sold over 6.8 million copies. However, I cannot be fully confident since I was not able to view a copy of the bum fights videos in its entirety, as it is illegal to distribute and dedicated fighting sites are unsafe to visit. Videos that depicted violence against a homeless person or an individual that was intended to be homeless followed approximately the same script with few variations. Even in videos that were clearly simulation, actors involved attempted to model the original episodes, modeling accents, phrases, dress code, and attributions of negative qualities towards individuals intended to be homeless in their videos. Simulations followed the "script" of the original bum hunter video.

In the original bum hunter video as well as the simulations, the hunter would start by welcoming the viewers to "another exciting episode of bum hunter!" When the bum hunter would introduce himself with his name, it was most commonly Steve Irwin or some other variation, like Crebe Sterwin adopting the persona of a crocodile hunter. 
Nearly all hunters spoke or attempted to speak with an Australian accent, modeling the original video and used words like "crikey" and "mate" frequently. Hunting for bums occurred roughly equally between day and night time hours. The bum hunter would then explain to the audience that he was in search of a bum. When the hunter tracked down the bum, who was usually sleeping, he would tie him up using zip ties, duct tape, or wrestle the bum and climb on top of him. By this point, the bum would become agitated and struggle and the bum hunter would attempt to soothe the bum by explaining that he just wanted to take a look at him, study him, take some measurements, and/or give him a tracking number. When the hunter would depart from the bum, he would run away quickly, so the bum could not catch him and retaliate. If the hunter bound up the bum, he would not always unbind him before he departed. On occasion, the hunter, with help from another hunter, would return him back to his natural habitat, where he belonged. In one case, the bum was returned to his natural habitat by throwing the bum in a lake and in another, the bum was rolled down a hill.

With the exception of one hunter and one bum, all individuals filmed were male and the majority of individuals were Caucasian. Both the hunters and the bums most frequently appeared to be between 14 and 16 years of age. Only in two scenes, the hunters come across more than one bum, in one scenario there were several hunters who were able to overpower the two bums. In the second scene with more than one bum, the film cut out before any analysis of the situation could be made. A large portion of the videos only had one bum hunter per scene; however, occasionally additional hunters would come in and assist in the immobilization of the bum if they were particularly difficult to wrangle. 


\section{What a Beautiful Specimen!}

In addition to referring to homeless persons as bums, the bum hunters also used the terms specimen, buck, bull, rare animal, and wild one to describe them, referring to them as creatures as opposed to human beings. Bum hunters stalk bums like prey and use clues that a bum would leave behind like remnants of food, bite marks on sticks, bum droppings, and the scent of a bum to find their location. Bums are considered rare animals by the bum hunters and this is conveyed through statements like "You normally find them in the areas of Seattle or Minneapolis even, sometimes in Mongolia, but it's very, very rare to find them here." The rarity of the bum conveys just how important it is for the bum hunter to study and document such specimens. One hunter explained that these types of bums, who live off the land, are much different from the kinds of bums who panhandle on street corners. This bum lifestyle is one that many do not even know exists:

I am TJ and I pride myself, over the years of being an expert on bums and on homeless people and their lifestyle and the underground network of the homeless person. Barring from your typical homeless person, laying on street corners, asking for spare change, or following you around asking for a cigarette. There is a whole other bum network that you or I don't even know about.

Hunters emphasized the need to measure and track bums, either to keep them out of harm's way and safe from "teenagers and street sweepers, and policemen" as one hunter explained or as a warning sign for individuals who come in contact with a bum, marked as dangerous. Hunters examined the clothing the bums were wearing, the objects in their possession, and their skin and hair, searching for specific traits the bums possess. When examining a bum, one hunter explained his intentions to the bum: 
It's for your own good mate; just want to study you here a little bit. Just layback, I want to check your flexibility levels. Oh, this is a beautiful specimen. Look at here, look at the receding hairline; obviously, this is one of the older bulls here.

Hunters explain the animal-like characteristics that bums posses, which help them adapt to their environment. One hunter observes a tattoo of a masquerade mask on a bum's neck and proclaims, "That means he's like a chameleon, he can change his colors whenever he likes." Another hunter explains how the bum defends himself from predators. The hunter goes on further to explain the different types of jackets bums wear designate their position in the bum pack hierarchy as well as the specific adaptations bums have for survival.

You notice the long legs on this sucker. Capable of gimping away from dangerous situations like fights and police precincts and notice the long dusty leather jacket, keeps him out of harm's way and also establishes his rank in the bum hierarchy. Look at the arm length; he uses those long arms to throw feces and other trash and items at people getting into his territory.

Bums are also very resourceful and make tools, utensils, shelters, and weapons from items they find.

Bums have distinct habitats and live in abandoned buildings, cardboard boxes, realms, dens, nests, and zones. Bums are territorial and special care needs to be taken when entering a bum territory. One hunter explained his preparation for entering the bum realm, so he could move about undetected:

I have prepared for this trek into the bum realm, the last week. I have not bathed. I have not shaved in the last several days so as to avoid any sort of cologne or after-shave situation. And uh, haven't really changed clothes, definitely worn the same underwear, so that all the smells, all the 
situations that the bum will be used to, he would not be afraid that anyone had been in his realm, in his den.

Two hunters felt that it was necessary for them to give bums baths. The hunter explained, "Now it's really important that we give him a good scrub, best for his own good and of course for society." In another instance, a bum hunter attempted to console the bum he had captured by telling him not to worry, that he was not going to give him a bath.

According to the bum hunters, several bums were not in their correct location and needed to be returned to their natural habitat or expelled from their current location. Hunters then proceeded to remove the bums and return them to their natural habitat, in one case by rolling a tied up bum down a hill and in another case, the bum was transported by van and thrown in a lake. In another instance, a hunter warned a bum about his current location, stating "this is a bum free zone, remember that!"

Bums are not only animals, but they are dangerous animals who will attack if a hunter is not careful. They are capable of springing from hiding places and scaring unsuspecting hunters. One bum hunter experienced a narrow escape, which he relays to the viewers:

We just got out of there; I had a real scary experience, if you see my hand here. When I was going in to actually wrap up that bum that we call Red, he got a hold of my pinky finger. My natural reaction would have been to pull back, but he could have ripped my arm straight off, instead, I let it go with him. I fell into the fall and my knee hit his head, and he released his bite. That's the last time I make that mistake with Red and next time, I've got that mark on him, so I know to stay away, far away from him.

Because bums are so dangerous, it is imperative that they be numbered and tracked. Hunters claim this is because they want to observe the bums, keep them out of harm's 
way, and enable the bum hunters to continue to track their movements. Bum hunters must also be prepared to capture or defend themselves from the bums. Hunters carried zip ties and duct tape to capture the bums. One hunter carried weapons other than zip ties and duct tape and called it a "bum stick" which was meant to be used fend off any dangerous bums, luckily no encounter ensued. The same hunter also carried cigarettes that he could throw at a bum to distract him while the hunter ran away. Among a group of hunters, one hunter was injured and in retaliation, the hunters threw approximately two cartons of eggs at the bum.

\section{It's a dirty job, but someone's gotta do it}

Hunting bums is not for the faint of heart, it takes skill, training, and courage. Hunters convey their professionalism through their uniforms, reiterating how dangerous bums are, and through their pride for their work. Hunters tend to wear brimmed hats, tan clothing, and boots as their uniform, which clearly distinguishes their role and influenced by the adopted crocodile hunter persona. Many hunters claim to have been hunting bums for quite some time and do not recommend those without training to do so. Also by introducing the video by stating, "welcome to another episode of bum hunter" leads the viewer to assume the video is part of a series.

Several videos boasted that the videos were put together by production companies. One video appeared to be so well established that it boasts its own logo, which was present in the lower right hand corner during the entire video. Several videos started with a montage of the hunter's previous encounters while hunting bums.

Hunters explain their actions to the audience, which conveys knowledge and skill when coming into contact with bums. One hunter states, "Welcome friends, I am TJ and 
I pride myself, over the years of being an expert on bums and on homeless people and their lifestyle and the underground network of the homeless person." Since bum hunting is so dangerous, professionals encourage viewers at home to leave this job to the professionals.

I'm back in the vehicle and I just wanted to say again, and stress to you at home, do not try this at home. I am a trained and experienced, seasoned professional, I've spent years, years studying the bums and going out to where they live, where they do the things that they do when you're not around, which is evidently going on here. The bums are definitely breeding out here so that means it's good for me, there's a lot more documentary footage that I can be shooting and a lot more we can learn about these people.

Hunters convey a sense of civic duty, that their job is difficult but necessary. Bums are described as drug using, mentally ill, criminals, alcoholics, and thieves and it is their duty to keep them in check. One hunter explains:

These are mean streets you know, I've been on them for like 5 or 6 years, I see a lot of bad things. I've had partners with cuts and bruises from these hobos its crazy I swear. It gets badder every year, we need more funds and stuff, it's horrible. It's just too bad, I mean I can't take it anymore, I mean it's a dirty job, but someone's gotta do it. But you know, it doesn't pay too well but it's my job and I need to have it, but it just gets worse and worse every time. I see more of these criminals and hobos who are lying around, it's just, it's too bad.

Bums are described as being smelly and stinky. In two instances, hunters explained the need for them to give the bum a bath that such actions were for the good of society. The hunters gave the bums baths using bristle brushes on the end of poles and stated; "Now it's really important that we give him a good scrub, best for his own good and of course for society." 


\section{Violence}

Of the 57 scenes, 39 scenes depicted physical violence against a person who was intended to be or appeared to be homeless. The majority of the violence depicted against homeless persons was both physical and psychological $(n=24)$. Physical violence was demonstrated against the bums by tying the bum up, using force to immobilize them, or kidnapping them $(n=30)$. Psychological aggression was used when bums were treated and referred to as animals, woken up by poking and prodding, all while being told that the hunter was not going to hurt them. The use of stereotypes, calling bums lazy, stinky, addicts, and referring to them as mentally ill $(n=9)$ and insults through treating bums as animals and scrutinizing their appearance $(n=27)$ were tactics of verbal aggression used towards the bums. Using nonverbal psychological aggression, hunters forced $(n=14)$, threatened and intimidated $(n=14)$ the bums to comply with their demands. The violation of the bum's human rights occurred when the hunter detained the bum and took them to another location, either to return them to their natural habitat or to give them a bath $(n=5)$.

Table 1

\begin{tabular}{lcc}
\hline Violence & Frequency & Percent \\
\hline Type of violence & & \\
No violence & 18 & 33.3 \\
Physical violence & 10 & 17.518 .5 \\
Psychological violence & 2 & 3.53 .7 \\
Physical and psychological violence & 24 & 44.4 \\
& & \\
Physical violence & & \\
No physical violence & 19 & 35.2 \\
Threatening/forcing & 1 & 1.9 \\
Fist fighting/pushing/striking & 2 & 3.7 \\
Hitting with weapons/tools/knockout & 1 & 1.9 \\
Kidnapping/tying up & 30 & 55.6 \\
Other & 1 & 1.9 \\
\hline
\end{tabular}


Verbal violence

No verbal aggression

Angry talk

Use of stereotypes

Mild personal insult

Verbal threat/humiliating

\section{Nonverbal violence}

No verbal aggression

Forcing/subjection/intimidation

Threatening/intimidation

Violating one's human rights

\section{Realization of violence}

None

31.5

Playful aggression

Threatening/hostile gesturing

Trying to insult

Insulting

Trying to kill

\section{Consequences of violence}

No consequences portrayed

No harm

Only material harm

Mild harm/injuries

Death

\section{Violent Intentions}

No perceived justification

Intentional/externally motivated

Unintentional/unconscious

\section{Violent motivations}

No perceived motivation

Both offensive and defensive

Offensive-instrumental

\section{Violent intentions}

No perceived justification

Intentional/externally motivated

10.9

Unintentional/unconscious

\section{Planning of violence}

Unable to determine

Planned/systematic

$\begin{array}{cc}3 & 6.8 \\ 41 & 93.2\end{array}$

Sex of aggressor

Male 
Age of aggressor

11-13 years old

14-16 years old

6.8

17-20 years old

47.7

21-25 years old

Sex of victim

Male

42

95.5

Group of males

2

4.5

Age of victim

11-13 years old

14-16 years old

17-20 years old

21-25 years old

26-30 years old

31-40 years old

41-50 years old

$\begin{array}{cc}3 & 6.8 \\ 21 & 47.7 \\ 4 & 9.1 \\ 2 & 4.5 \\ 1 & 2.3 \\ 10 & 22.7 \\ 3 & 6.8\end{array}$

\section{Length of violence}

6-15 seconds

16-30 seconds

30-60 seconds

More than 60 seconds

$\begin{array}{cc}2 & 4.5 \\ 2 & 4.5 \\ 22 & 50 \\ 18 & 40.9\end{array}$

\section{Atmosphere}

Humorous/comic

Quarrelsome

\section{Clarity}

Unclear depiction

29.5

Clear depiction

Intensity of violence

Mild

Moderate

31

50

Brutal

66

$12 \quad 27$

37

\section{Nature of aggressor}

Neutral/ordinary

Hero

\section{Nature of victim}

Villain

Animal

7

16

36

84

Ignoring the consequences

No consequences depicted

36

80

Consequences partially depicted

4

Consequences depicted as hints

$5 \quad 11.1$




\begin{tabular}{lcc}
\hline Gratification from violence & & \\
Little gratification & 1 & 2.2 \\
Partial gratification & 8 & 17.8 \\
Complete gratification & 36 & 80 \\
& & \\
Overall attractiveness of violence & & 7 \\
Moderate/neutral & 3 & 93 \\
Attractive & 40 & \\
\hline
\end{tabular}

Consequences of the bum hunter's catch and release actions against the bums were rarely shown $(n=33)$. Two videos showed any type of retaliation from the bums. In one case, the hunter returned with a bloody pinky finger and in another instance, the bum stole the hunter's car, which they ultimately got back. The bum hunters were shown as gaining full gratification from their actions taken against the bums. Because there were little if any consequences of the bum hunter's action shown, this made such violence overall appear attractive in the majority of the videos $(n=40)$.

The majority of the perceived intentions of the bum hunter's actions towards the bums were intentional and externally motivated $(n=32)$ as well as offensive and instrumental. The hunters described their plan of attack to the audience and violence was initiated by the bum hunter $(n=41)$ rather than violence produced by spontaneous actions. All aggressors were males on their own or in groups. The only female hunter within the sample did not perpetrate violence against the bum. All hunters were between the perceived ages of 11 and 25, with the largest amount of hunters appearing to be between the ages of 14 and $16(n=21)$. All bums, who were the victims in the videos were male, there were two groups of male victims and the remaining were solo $(n=42)$. The perceived age of the victims range from 11 to 50 , with the most being between the ages of 11 to $13(n=21)$ and the second most being between the ages of 31-40 years old $(n=10)$. 
A large portion of the violent acts were between 30 to 60 seconds in length $(\mathrm{n}=$ 22) and over 60 seconds in length $(n=18)$. The atmosphere created during the violence was largely quarrelsome $(n=37)$ and in the remaining videos, the atmosphere was humorous $(n=7)$. In 13 of the videos portraying violence, the video quality was unclear, and 31 of the videos had clear quality. The intensity of the violence was mostly mild $(\mathrm{n}=$ 29), in twelve videos the violence was moderate, and in three videos the violence appeared brutal. In the brutal video, it appears that the bum had drowned when the hunters were giving him a bath in a pool. Nearly all of the bum hunters were depicted as heroes in the videos $(n=40)$ and nearly all the bums were depicted as animals in the videos $(\mathrm{n}=36)$.

\section{Twisting Simulation}

Several of the videos did not adhere as strictly to the original bum hunter scripts as the majority of the sample; however, they utilized aspects of the bum hunter's role. Two videos added the audio of the original bum hunter to a recording of a violent video game, in which the dialogue suggested that their character was the bum hunter. The characters would attempt to lure the bum by telling them "relax their mate; I'm not going to hurt you." One video was of a band performance entitled "Bum Hunter" and the lyrics reinforced negative stereotypes about the homeless and ended with "find a job you stinky bum."

Other videos used the stalking approach of the bum hunter to sneak up on unsuspecting friends and family. In these videos, the hunter would identify himself as the bum hunter, layout the plan of action and then go in search of a bum. It was very clear that the individuals in the hunter and bum roles were inside a house. Negative attributes 
were tied to the sleeping bum by accusing them of theft or being lazy. In other instances, the bum knowingly played along with the hunter. In these cases, it was also typical for both the hunter and the bum to laugh frequently while the hunter was attempting to wrestle the bum to the ground. 


\section{CHAPTER V}

\section{DISCUSSION AND CONCLUSION}

\section{Discussion}

Even if in reality, no homeless individuals were harmed in any of the analyzed videos, such videos still convey negative messages about the homeless population. Videos highlight the negative views that our society holds about the homeless, that homeless individuals are acceptable targets for victimization, and need to be controlled. Hunters explain that bums are lazy, stinky, drug users who live off the grid and outside of society. By treating and thinking of homeless individuals as animals, negative actions are neutralized and they become appropriate targets (Sykes \& Matza, 1957). Hunters see their actions as necessary for the well-being of bums and for society (Becker, 1967).

Bums were typically found in isolation from others, which situated them as suitable targets for the bum hunters (Cohen \& Felson, 1979). In addition, all bums were shown to be individuals who lived outside, in abandoned buildings, and secluded parking lots, leaving them exposed to victimization (Meier \& Meithe, 1993). Even without knowing any specifics about any of the bums hunted, hunters were able to attribute specific characteristics to the bums due to their stigmatized identity (Goffman, 1959; 
Gramlich, 2008). The hunters described bums to be drug and alcohol users, thieves, mentally ill, and lazy all based upon their homeless appearance (Raskin, Harasum, Mercuri, \& Widrick, 2008).

Bum hunters neutralized their actions through referring to and treating homeless individuals like animals, which are socially acceptable targets for capture and release methods (Sykes \& Matza, 1957). In this way, hunters justified their actions by conveying that they were conducting research on a rare animal or looking out for the bum's wellbeing, or of the safety of the nearby domiciled populations. Treating homeless persons like animals, also neutralizes the use of violence because animals are unpredictable and dangerous (Sykes \& Matza, 1957). Tracking gives the hunters control over bums and allows hunters to regulate disorderly behavior or return them to their natural habitat. Such actions also reinforce the acceptable usage of space as being confined to marginal and transitional spaces (Snow \& Anderson, 1993) and remove bums, which are signs of disorder (Wilson \& Kelling, 1982).

Hunters see themselves as providing the community with valuable skills, which keep bums in check and orderly or expels them from their current location. Their uniforms identify their roles and credibility, symbolizing knowledge and expertise, much like a police officer's uniform does. Hunter's emphasize their training and knowledge and do not recommend that novices take part. In this way, hunters neutralize their actions by viewing bums as appropriate targets for action because they disrupt order and themselves as moral entrepreneurs who uphold the values of society (Becker, 1963; Sykes \& Matza, 1957). The majority of violent actions taken against the bums appeared to be planned, intentional and externally motivated. Hunters claim that they are working 
in the best interest of the bums and/or the domiciled population (Becker, 1963). Through the hunter's emphasis on the difficulty of the job, they are highlighting the importance of the role in the wellbeing of the community, "it's a dirty job, but someone's gotta do it."

Similar to individuals that the $\mathrm{NCH}$ has documented as individuals who physically victimize homeless individuals, bum hunters portrayed in the videos were under the age of 25 and male. Violence against bums was depicted without consequence. Lack of consequences denies that there was even a victim and neutralizes such actions (Sykes \& Matza, 1957). If there are seemingly no consequences for the bum hunter's actions, it is possible that others will attempt to emulate them.

Even videos that loosely simulated the bum hunter's actions still convey the same message, albeit a weaker message (Baurillard, 2006). In addition, videos that were loose simulations also signify that it is likely that the role of the bum hunter has been internalized by the viewer. This is likely because the creators still considered such videos to be tied to the original bum hunter enough to title it the same (Mulvey, 1975). These findings could indicate how broad the internalized view of the bum hunter can be. In addition, findings could also indicate the range of possibilities when demonstrating negative views toward homeless persons. For example, when using the hunting methods of the bum hunter on a sleeping friend, commonly the individual in the hunter role would state that the individual is lazy or a thief, both qualities that the bum hunting videos attributed to "bums." However, more research is needed to understand more about the internalized view of the bum hunter.

The current study looked at a specific group of videos within the larger group of bum fighting, future studies could look at all videos with negative actions taken against 
the homeless. Future studies could survey individuals that have viewed the bum fights videos in relation to individuals who have not. Surveying such individuals would attempt to understand just how and under what conditions, individuals internalize the role of the bum hunter as well as other aggressors of homeless persons. Do the bum fights videos create prejudice and discrimination against homeless individuals? Do the bum fights videos reinforce prejudice and discrimination against homeless individuals? Do the bum fights videos encourage individuals to display prejudice and discrimination against homeless individuals? Do the bum fight videos encourage individuals to produce their own videos?

\section{Policy Implications: Protect Homeless under Federal Hate Crime Statutes}

Under current legislation, violent acts against the homeless are not considered hate crimes (NCH, 2009). However, since 1999, approximately 244 homeless individuals have died due to attacks, whereas 94 individuals have died because of a hate crime due to race, color, religion, national origin, or sexual orientation, which illustrates the severity and intensity of attacks against homeless persons ( $\mathrm{NCH}, 2009: 32)$. In an $\mathrm{NCH}$ report, Brian Levin explains, that these attacks have been "Unprovoked targeted attacks by predominantly domiciled young male assailants that do not involve robbery, personal disputes, or drug dealing" (NCH, 2009). Then NCH and NLCHP propose The Hate Crimes Against the Homeless Enforcement Act and the Hate Crimes Against the Homeless Statistics Act, which would categorize violent acts taken against the homeless as hate crimes and keep national statistics on hate crimes against the homeless (2007). This legislation would clearly express that violence against the homeless is not tolerated. The NCH \& NLCHP explain in their 2007 address to congress, "When the government 
passes laws that discriminate against a powerless group, it gives a green light to those who would engage in acts of violence." Not only does action need to be taken to categorize violent acts against the homeless as hate crimes, but efforts also need to be taken to decriminalize aspects of homelessness.

\section{Policy Implications: Decriminalize the Homeless}

Actions that criminalize homeless persons also create an environment that is structurally conducive for their victimization. By reducing or removing the stigma and criminal label that is placed on homeless persons, it seems likely that a reduction a in their victimization would also occur. For example, in Louisville, Kentucky, an ordinance was passed in 2007 that prohibited aggressive solicitation and panhandling. Ordinance No. 291 states, "Aggressive solicitation usually includes approaching or following pedestrians, repetitive soliciting despite refusals, the use of abusive or profane language to cause fear and intimidation, unwanted physical contact, or the intentional blocking of vehicular and pedestrian traffic" (Tandy \& Unseld, 2007:1-2).

While many may see panhandling as an issue, criminalizing those who do so is not an appropriate action. Individuals who turn to panhandling as a survival strategy, are more than likely do so because other options have been exhausted or do not provide for all of an individual's needs. By criminalizing the homeless, not only are they further stigmatized, but they also face additional blocked access to social support and the workforce, which actually may increase an individual's problems.

The issues of homelessness are difficult to eradicate and many social service providers are already attempting to solve this issue. Three alternatives are outlined in order to decriminalize homelessness and augment the services already being provided 
within the metro area. The attention should center on ways to educate law enforcement on issues of homelessness and providing constructive ways for officers to address homelessness. In addition, by teaching about structural causes of homelessness in the school systems and through organized interactions with homeless persons, it seems likely that students would gain greater understanding for issues of homelessness (Lee, et al., 2004). Finally, non-violent offenses could be settled while catering the specific need of the homeless population. The focus should also be on addressing the needs of the homeless as a tool for removing individuals from the street rather than sending individuals to jail or being labeled as criminals.

\section{Solution No. 1: Police Referrals}

This alternative is a combination of assistance provided to homeless persons in Ft. Lauderdale, Florida as well as services provided to victims of domestic violence and sexual assault in Louisville, Kentucky. The ordinance in Louisville, Kentucky, which prohibits panhandling, would still be in place; however, such measures would only be used as a last resort. This solution ties together existing organizations to law enforcement in an effort to minimize the need for panhandling and to directly link homeless individuals to existing services that are provided for persons in need.

The NLCHP suggests that law enforcement should use legal action against homeless persons once all other avenues have been exhausted. The NLCHP has created a guide for law enforcement when interacting with the homeless that illustrates suggested actions for different situations involving homeless individuals that focus on their rights as citizens rather than labeling them as criminals (NLCHP, n.d.). Police officers are also educated on the causes of homelessness and why such alternatives are needed to help the 
homeless (Liese, 2006). Officers are not to tell an individual who appears homeless to 'move on' or initiate contact with the individual because of their homeless status. In addition, the guide also suggests to officers that they contact homeless outreach workers that can offer assistance to homeless persons, but action cannot be taken against them if they decide against receiving aid. Fort Lauderdale has found particular success with this method of interaction with the homeless, in which advocates educating officers on the causes of homelessness and connect law enforcement with referral agencies. As a result, "The Fort Lauderdale [Homelessness Assistance] Center estimates that approximately 50 percent of their clients come from police referrals" and that out of the approximately 1,000 individuals approached by officers, 680 individuals have sought help from the services they were linked with through officer intervention (Liese, 2006: 1453).

\section{Solution No. 2: Teaching about Homelessness}

This alternative works in conjunction with schools to teach students about the structural causes of homelessness. Lee, Farrell, and Link (2004) found that respondents in their national study who had greater exposure to persons experiencing homelessness were more likely to link homelessness with its structural factors. Through increased exposure, individuals go through the process of simple learning, in which exposure provides new information for dominant group members, which then reduces the need to use stereotypes (Lee, et al., 2004).

When students learn about homeless persons and structural causes of homelessness it is likely that they will be more understanding and empathic towards the homeless. Through classroom learning, guest speakers who are homeless or formerly homeless could speak to students about the individual issues that they faced while being 
homeless. The $\mathrm{NCH}$ has developed course curriculum for students from kindergarten to high school. Lesson plans focus on what it means to be homeless, why people are homeless, highlighting the similarities between a domiciled individual and homeless individual (NCH, 2008a). In addition to in class work, students could also volunteer their time collecting canned goods, volunteering at a food bank, or volunteering at a soup kitchen to gain greater insight about the difficulties of homelessness.

\section{Solution No. 3: Homeless Court Program}

This solution would set up a Homeless Court Program, which builds a coalition between the judicial system and advocates for the homeless. The ordinance, which prohibits panhandling, would still be in place; however, such measures would limit the severity of the charges. Special monthly courts are set up to meet within homeless shelters to resolve outstanding misdemeanor criminal charges. Holding court proceedings inside the shelter permits other persons experiencing homelessness to speak on the defendant's behalf; in addition, it allows those individuals to focus on matters much more pertinent to survival like finding food, shelter, and employment opportunities. As well, homeless individuals may find it difficult to go to court if they have mental illnesses or quite possibly because they are afraid of the system, afraid of going to jail, afraid because they may not understand the system, etc. Moreover, if a homeless individual enters a courthouse, they may not have anywhere to safely store their belongings. The Homeless Court System removes these barriers for homeless individuals and brings the court process to them (Binder, 2002; NCH \& NCLHP, 2006).

Such an agreement allows homeless individuals to remove the barriers of outstanding charges when seeking to rebuild their lives (Binder, 2002; NCH \& NCLHP, 
2006). Homeless Court Programs aid in the reduction of jail and court costs, improve access homeless individuals have to the court system, as well as aid in the locating of other important services and employment opportunities (Binder, 2002). This type of court system also use a progressive system of plea-bargaining in which homeless individuals are evaluated on the actions they have taken to better their situation. Alternative forms of sentencing are also used in which the individual is encouraged to participate in shelter activities to better their situation and work towards self-sufficiency (Binder, 2002; NCH \& NCLHP, 2006).

The Homeless Court Program was successfully created by Steven R. Binder in San Diego, in 1989 and the Homeless Court Program has been replicated in twenty cities across the nation (NCH \& NCLHP, 2006). Individuals are not forced to use the system, rather it is their responsibility to sign up to resolve their charges. Individuals that have gone through the process explained that they felt they were able to start over and were able to gain confidence. In addition, of those who have gone through the program 46 percent went on to seek permanent housing, 39 percent applied for a driver's license, and 38 percent sought employment (Binder, 2002; NCH \& NCLHP, 2006).

\section{Conclusion}

Until we alter the way society views homelessness, it is likely that violent actions taken against the homeless will continue. The mentality of American society situates individuals who do not follow the individualist ideology (Robinson, 2009) to be responsible for their own failings. Since hard work is valued, those who do not work, or are unable to attain middle class standing are subject to ridicule. Currently, homeless individuals are seen as indicators of disorder and undesirable; this is reflected in the 
number of laws nationwide that criminalize aspects of homelessness. By criminalizing such activities as loitering, panhandling, and sleep outside this conveys a message in which homeless individuals are unwanted by society and leaves them subject to victimization. Viewing homeless individuals in this light creates a structurally conducive atmosphere for individuals to cause harm to the homeless.

Efforts need to be taken to enable society to see the full spectrum of causes of homelessness, understanding that there are both structural causes, which are out of the control of the individual, as well as individual circumstances which an individual may have some control over. Categorizing violent acts taken against the homeless and taking efforts towards decriminalizing homeless individuals in the eyes of law enforcement and society are tangible steps that can be taken towards reducing the victimization of the homeless population. 


\section{REFERENCES}

2007 "National Law Center on Homelessness \& Poverty Congressional Briefing on HR 2216 \& 2217." Congress: The National Coalition for the Homeless and the National Law Center on Homelessness and Poverty.

60 Minutes. 2006. "Bumfights Videos Inspired Joy-Killing."

Altheide, David L. 1987. "Ethnographic content analysis." Qualitative Sociology 10:6577.

Altheide, David L. 1996. Qualitative Media Analysis. Thousand Oaks: Sage.

Amster, Randall. 2003. "Patterns of exclusion: Sanitizing space, criminalizing homelessness." Social Justice 30:195-221.

Barak, Gregg and Robert M. Bohm. 1989. "The crimes of the homeless or the crime of homelessness? On dialects of criminalization, decriminalization, and victimization." Contemporary Crises 13:275-288.

Baudrillard, Jean. 2006. Simulacra and Simulation. Translated by S. F. Glaser: The University of Michigan.

Bauman, Donald J., Cheryl Beauvais, Charles Grigsby, and Franklin Schultz. 1985. "The Austin homeless: Final report provided to the Hogg foundation for mental health." Hogg Foundation for mental health, Austin, Texas.

Becker, Howard S. 1963. Outsiders: Studies in the sociology of deviance. New York: The Free Press.

Belchner, J. R. 1989. "On becoming homeless: A study of chronically mentally ill persons." Journal of Community Psychology 17:173-185.

Bellah, Robert N., Richard Madsen, William M. Sullivan, Ann Swindler, and Steven M. Tipton. 1985. Habits of the Heart: Individualism and Commitments in American Life. Berkley: University of California Press.

Binder, Steven R. 2002. "The Homeless Court Program: Taking the Court to the Streets." American Bar Association Commission on Homelessness and Poverty Washington, DC. 
Blau, Joel. 1992. The Visible Poor: Homelessness in the United States. New York: Oxford University Press.

Bluestone, Barry and Bennett Harrison. 1982. The Deindustrialization of America. New York: Basic Books.

Breton, M. and T. Bunston. 1992. "Physical violence in the lives of homeless women." Canadian Journal of Community Mental Health 11:29-44.

Burchfield, K. B. 2009. "Attachment as a source of informal social control in urban neighborhoods." Journal of Criminal Justice 37:45-54.

Burgess, Jean and Joshua Green. 2009. YouTube: Online Video and Participatory Culture. Cambridge: Polity Press.

Cha, Meeyoung, Haewoon Kwak, Pablo Rodriguez, Yong-Yeol Ahn, and Sue Moon. 2007. "I tube, you tube everybody tubes: Analyzing the largest user generated content video system." IMC October.

Cohen, Lawrence E. and Marcus Felson. 1979. "Social change and crime rate trends: A routine activity approach." American Sociological Review 44:588-608.

Debord, Guy. 1994. The Society of the Spectacle. Translated by D. Nicholson-Smith: MIT Press.

Duncan, James S. 1983. Men without property: The tramp's classification and use of urban space, Edited by R. W. Lake. New Brunswick: Rutgers University Press.

Ehrenreich, Barbara. 2001. Nickeled and Dimed: On (Not) Getting By in America. New York: Metropolitan Books.

Elliott, Marta and Lauren J. Krivo. 1991. "Structural determinants of homelessness in the United States." Social Problems 39:113-131.

Farrell, Chad R. 2005. "Sharing neighborhoods: Order and disorder in homelessdomiciled encounters." American Behavioral Scientist 48:1033-1054.

Felluga, Dino. 2002. "Modules on Baudrillard: On Simulation" Introductory Guide to Critical Theory, Retrieved April 21, 2009

(http://www.purdue.edu/guidetotheory/postmodernism/modules/baudrillardsimula tion.html).

Fernandez-Villanueva, C., J. C. Revilla-Castro, R. Dominguez-Bilbao, L. GimenoJimenez, and A. Almagro. 2009. "Gender Differences in the Representation of Violence on Spanish Television: Should Women be More Violent?" Sex Roles 61:85-100.

Ferrell, Jeff, Keith Hayward, and Jock Young. 2008. Cultural Criminology. London: Sage. 
Fischer, P. J. 1992. "Victimization and homelessness: Cause and effect." Pp. 229-246 in Homelessness: New England and beyond, edited by P. O'Malley. Baltimore: Johns Hopkins University Press.

Fischer, Sean N., Marybeth Shinn, Patrick Shrout, and Sam Tsemberis. 2008. "Homelessness, mental illness, and criminal activity: Examining patterns over time." American Journal of Community Psychology 42:251-265.

Fisher, B., M. Hovell, C. R. Hofstetter, and R. Hough. 1995. "Risks associated with long-term homelessness among women: Battery, rape, and HIV infection." International Journal of Health Services 25:351-369.

Fitzpatrick, K. M., M. E. La Gory, and F. J. Ritchey. 1993. "Criminal victimization among the homeless." Justice Quarterly 10:353-368.

Flynn, Nicole T. 2003. "The differential effect of labor market context on marginal employment outcomes." Sociological Spectrum 23:305-330.

Gaetz, Stephen. 2004. "Safe streets from whom? Homeless youth, social exclusion, and criminal victimization." Canadian Journal of Criminology and Criminal Justice July:423-455.

Glaser, B. and A. Strauss. 1967. The Discovery of Grounded Theory. Chicago: Aldine.

Glaser, Barney with Judith Holton. 2004. "Remodeling grounded theory " Forum: Qualitative Social Research 5.

Goffman, Erving. 1959. The Presentation of Self in Everyday Life. Garden City, NY: Doubleday Anchor.

Goldstein, B. J. 1993. "Panhandlers at Yale: A case study in the limits of the law." Indiana Law Review 27:295-359.

Gramlich, James Jude. 2008. "Adaptation and self-presentation among homeless street people: Making the invisible visible." Sociology Department, University of Illinois at Chicago, Chicago.

Haas, Brian and Jamie Malernee. 2006. "Outrage at 'senseless attacks: 1 dead, 2 injured in beatings of homeless." in Sun Sentinel. Ft. Lauderdale.

Harcourt, Bernard E. 2001. Illusion of Order: The False Promise of Broken Windows Policing United States: Harvard University Press.

Haridakis, Paul and Gary Hanson. 2009. "Social interaction and co-viewing with YouTube: Blending mass communication reception and social connection." Journal of Broadcasting \& Electronic Media 53:317-335.

Hayward, Keith and Jock Young. 2004. "Cultural criminology: Some notes on the script." Special edition of the International Journal of Theoretical Criminology 8:259285. 
Hindelang, Michael S., Michael Gottfredson, and James Garofalo. 1978. Victims of Personal Crime. Cambridge, Mass.: Ballinger.

Hodulik, Jennifer. 2001. "Comments: The drug court model as response to "broken windows" criminal justice for th homeless mentally ill." The Journal of Criminal Law \& Criminology 91:1073-1100.

Huber, Joan and William Form. 1973. INCOME and IDEOLOGY: An Analysis of the American Political Formula. New York: The Free Press.

Hudson, Kenneth and Andrea Coukos. 2005. "The dark side of the Protestant ethic: A comparative analysis of welfare reform." Sociological Theory 23:1-24.

Institute of Medicine. 1988. Homelessness, Health, and Human Needs. Washington, D.C.: National Academy Press.

Jasinski, J. L., J. Wesley, E. Mustaine, and J. D. Wright. 2005. "The experience of violence in the lives of homeless women: A research report." National Institute of Justice, Washington, DC.

Jencks, C. 1994. The Homeless. Cambridge: Harvard University Press.

Jenkins, Henry. 2006. Convergence Culture: Where new and old media collide. New York: Routledge.

Kalleberg, Arne, Barbara Reskin, and Ken Hudson. 2000. "Bad Jobs in America: Standard and Nonstandard Employment Relations and Job Quality in the United States." American Sociological Review 65:256-278.

Karmen, Andrew. 1984. Crime Victims: An Introduction to Victimology. Belmont, CA: Cole Publishing.

Katz, Michael B. 1989. The Undeserving Poor: From the War on Poverty to the War on Welfare. New York: Random House.

- 1996. In the shadow of the poorhouse: A social history of welfare in America. New York: Basic Books.

Kelso, William A. 1994. Poverty and the Underclass: Changing Perceptions of the Poor in America. New York: New York University Press.

Kilpatrick, D. G. and R. Acierno. 2003. "Mental health needs of crime victims: Epidemiology and outcome." Journal of Traumatic Stress 16:119-132.

Kilpatrick, D. G., R. Acierno, H. Resuick, B. E. Saunders, and C. L. Best. 1997. "A 2year longitudinal analysis of relationships between violent assault and substance abuse in women." Journal of Consulting and Clinical Psychology 65:835-847.

Klepal, Dan. 2007. "Metro Council OKs restrictions on panhandling." in The CourierJournal. Louisville. 
Kluegel, James R. 1987. "Macro-economic problems, beliefs about the poor and attitudes toward welfare spending." Social Problems 34:82-99.

Kushel, M. B., J. L. Evans, S. Perry, M. J. Robertson, and A. R. Moss. 2003. "No door to lock: Victimization among homeless and marginally housed persons." Archives of Internal Medicine 163:2492-2499.

Lam, J. A. and R. Rosenbeck. 1998. "The effect of victimization on clinical outcomes of homeless persons with serious mental illness." Psychiatric Services 49:678-683.

Lee, A Barrett and Chad R. Farrell. 2003. "Buddy can you spare a dime? Homelessness, panhandling, and the public." Urban Affairs Review 38:299-324.

Lee, A Barrett, Chad R. Farrell, and Bruce G. Link. 2004. "Revisiting the contact hypothesis: The case of public exposure to homelessness." American Sociological Review 69:40-63.

Lee, A Barrett, Sue Hinze Jones, and David W. Lewis. 1990. "Public beliefs about the causes of homelessness." Social Forces 69:253-265.

Lee, A Barrett, David W. Lewis, and Sue Hinze Jones. 1992. "Are the homeless to blame? A test of two theories." Sociological Quarterly 33:535-552.

Lee, Barrett A. and Christopher J. Schreck. 2005. "Danger on the streets: Marginality and victimization among homeless people." American Behavioral Scientist 48:10551081 .

Liese, Andrew J. 2006. "We can do better: Anti-homeless ordinances as violations of state substantive due process of law." Vanderbilt Law Review 59:1413-1455.

Logan, J. R. and H. L. Molotch. 1987. Urban Fortunes: The political economy of place. New York: Basic Books.

Maruna, Shadd and Heith Copes. 2005. "What have we learned from five decades of neutralization research?" Crime and Justice 32: 211- 320.

Meier, Robert F. and Terrance D. Miethe. 1993. "Understanding theories of criminal victimization." Crime and Justice 17:459-499.

Miller, Henry. 1991. On the Fringe: The Dispossessed in America. Toronto: Lexington.

-. 2000. On the Fringe: The Dispossessed in America. Toronto: Lexington.

Mock, Brentin. 2007. "Hating the Homeless: Attacks on homeless rise across nation." Intelligence Report Summer

Molloy, Aimee. 2006. "Degradation Inc." in The New York Times. New York City.

Moriarty, Shannon. 2009, "Why are "bum fight" videos rising in popularity?", Retrieved March 30, 2010 (www.change.org). 
Mulvey, Laura. 1975. "Visual Pleasure and Narrative Cinema." Screen 16:6-18.

Mustonen, A. 1997. "Nature of screen violence and its relation to program popularity." Aggressive Behavior 23:281-292.

Mustonen, Anu and Lea Pulkkinen. 1997. "Television violence: A development of a coding scheme." Journal of Broadcasting \& Electronic Media 41.

National Coalition for the Homeless. 2007. "Hate, Violence, and Death on Main Street USA: A Report on Hate Crimes and Violence Against People Experiencing Homelessness 2006."

—. 2008a. "Homelessness Fact Sheet for Kindergarten-Second Grade Students." Washington D.C.

—. 2008b. "Hate, Violence, and Death on Main Street USA: A Report on Hate Crimes and Violence Against People Experiencing Homelessness 2007 ".

—. 2009. "Hate, Violence, and Death on Main Street USA: A Report on Hate Crimes and Violence Against People Experiencing Homelessness 2008."

National Coalition for the Homeless and National Law Center on Homelessness \& Poverty. 2006. "A dream denied: The criminalization of homelessness in U.S. cities." The National Coalition for the Homeless and The National Law Center on Homelessness \& Poverty.

National Law Center on Homelessness \& Poverty. 2002. "Combating the criminalization of homelessness: A guide to understand and prevent legislation that criminalizes life-sustaining activities." National Law Center on Homelessness \& Poverty.

—. n.d. "Model general order: Handling interactions with homeless persons." edited by National Law Center on Homelessness \& Poverty.

No Author. 2006. "An American Tragedy: Hunger, Homelessness in the Land of Plenty 2006 Survey Released." in U.S. Mayor Newspaper.

Paisley, W. J. 1969. "Studying "style" as deviation from encoding norms." in The analysis of communication content: Developments in scientific theories and computer techniques, edited by G. Gerbner, O. R. Holsti, L. Krippendorff, W. J. Paisley, and P. J. Stone. New York: Wiley.

Perron, Brian Edward, Ben Alexander-Eitzman, David F. Gillespie, and David Pollio. 2008. "Modeling the mental health effects of victimization among homeless persons." Social Science \& Medicine 67:1475-1479.

Perry, Tony. 2006. "'Bumfights' producers throw in the towel." in Los Angeles Times. Los Angeles. 
Phelan, Jo, Bruce G. Link, Moore Robert E., and Ann Stueve. 1997. "The Stigma of Homelessness: The Impact of the Label "Homeless" on Attitudes Toward Poor Persons." Social Psychology Quarterly 60:323-337.

Quinney, Richard. 1980. Class, State, and Crime. New York: Longman.

Rand, Michael R. 2008. "Criminal Victimization, 2007." Bureau of Justice Statistics Washington DC.

Raskin, Jonathan D., Melanie T. Harasum, Matthew A. Mercuri, and Rebekah M. Widrick. 2008. "Constructing stigmatized identities: A gold selection study." Psychology and Psychotherapy: Theory, Research and Practice 81:285-296.

Robertson, Majorie J., Richard Ropers, and Richard Boyer. 1985. "The homeless of Los Angeles County: An empirical evaluation." School of Public Health, University of California, Los Angeles.

Robinson, J. W. 2009. " American poverty cause beliefs and structured inequality legitimation." Sociological Spectrum 29:489-518.

Romich, Jennifer L., Jennifer Simmelink, and Stephen D. Holt. 2007. "When Working Harder Does Not PAy: Low-Income Working Families, Tax Liabilities, and Benefit Reductions." Families in Society 88:418-426.

Rossi, Peter H. 1989. Down and Out in America: The origins of homelessness. Chicago: University of Chicago Press.

Rubin, A. M., Paul Haridakis, G. A. Hullman, S. Sun, P. M. Chikombero, and V. Pornsakulvanich. 2003. "Television exposure not predictive of terrorism fear." Newspaper Research Journal 24:128-145.

Sampson, Robert J. and W. Byron Groves. 1989. "Community Structure and Crime: Testing Social-Disorganization Theory." The American Journal of Sociology 94:774-802.

Segal, Elizabeth A. 2007. "Social Empathy: A Tool to Address the Contradiction of Working But Still Poor." Families in Society 88:333-337.

Sernau, Scott. 2006. Worlds Apart: Social inequalities in a global economy. Thousand Oaks: Sage.

Shapiro, Robert Y., Kelly D. Patterson, Judith Russell, and John T. Young. 1987. "The polls: Public assistance." Public Opinion Quarterly 51:120-130.

Shaw, Clifford and Henry McKay. 1942. Juvenile Delinquency and Urban Areas. Chicago: University of Chicago Press.

Shlay, Anne B. and Peter H. Rossi. 1992. "Social science research and contemporary studies of homelessness." Annual Review Sociology 18:129-160. 
Simon, H. 1996. "Municipal regulation of the homeless in public spaces." in Homelessness in America, edited by J. Baumohl. Phoenix: Oryx.

Slater, Samuel. 2005. "The commodification of violence on the internet: An analysis of 166 websites containing commodified violence." Internet Journal of Criminology.

Smith, Tom W. 1987. "That which we call welfare by any other name would smell sweeter." Public Opinion Quarterly 51:75-83.

Smith, Vicki. 1998. "The Fractured World of the Temporary Workers: Power, Participation, and Fragmentation in the Contemporary Workplace." Social Problems 45:411-430.

Snow, D. A. and M. Mulcahy. 2001. "Space, politics, and the survival strategies of the homeless." American Behavioral Scientist 45.

Snow, David A. and Leon Anderson. 1993. Down on Their Luck: A Study of Homeless Street People. Berkley: University of California Press.

Snow, David A., Susan G. Baker, and Leon Anderson. 1989. "Criminality and homeless men: An empirical assessment." Social Problems 36:532-549.

Sorenson, S.B. and J. M. Golding. 1990. "Depressive sequelae of recent criminal victimization." Journal of Traumatic Stress 3:337-350.

Spicker, Paul. 1984. Stigma and Social Welfare. London: Croom Helm.

Spitzer, S. 1975. "Towards a Marxian theory of deviance." Social Problems 22:638-651.

Stricker, Frank. 2007. Why America Lost the War on Poverty--And How to Win It. Chapel Hill: University of North Carolina Press.

Swanson, J. 2001. Poor Bashing. Toronto: Between the Lines.

Sweet, Stephen and Peter Meiksins. 2008. Changing Contours of Work: Jobs and Opportunitites in the New Economy. Thousand Oaks, CA: Pine Forge Press.

Sykes, Gresham M. and David Matza. 1957. "Techniques of neutralization: A theory of delinquency." American Sociological Review 22:664-670.

Tandy, David and George Unseld. 2007. "Code of Ordinances Relating to Panhandling." in 132.03(A)(19), edited by The Louisville/Jefferson County Metro Government.

Thompsett, Carolyn J., Paul A. Toro, Melissa Guzicki, Manuel Manrique, and Jigna Zatakia. 2006. "Homelessness in the United States: Assessing changes in prevalence and public opinion, 1993-2001." American Journal of Community Psychology 37:47-61.

U.S. Department of Housing and Urban Development. 2007. "McKinney-Vento Act." U.S. Department of Housing and Urban Development. 
Vitale, Alex S. 2005. "Innovation and Institutionalization: Factors in the Development of "Quality of Life" Policing in New York City." Policing \& Society 15:99-124.

Wachholz, S. and R. Mullaly. 1993. "Policing the deinstitutionalized mentally ill: Toward an understanding of its function." Crime, Law and Social Change 19:281-300.

Wachholz, Sandra. 2005. "Hate Crimes Against the Homeless: Warning-Out New England Style." Journal of Sociology and Social Welfare 32:141-163.

Walker, Alan and Carol Walker. 1997. "Britain divided: The growth of social exclusion in the 1980s and 1990s." London: Child Poverty Advocacy Group.

Weaver, Kent R., Robert Y. Shapiro, and Lawrence R. Jacobs. 1995. "The polls--trends: Welfare." Public Opinion Quarterly 59:606-627.

Weber, Max. [1905] [1958] 1976. The Spirit of Capitalism and the Protestant Ethic. Translated by T. Parsons. New York: Charles Scribner's Sons.

Wenzel, Suzanne L., Barbara D. Leake, and Lillian Gelberg. 2001. "Risk factors for major violence among homeless women." Journal of Interpersonal Violence 16:739-752.

Williams, Robert M. Jr. 1947. The Reduction of Intergroup Tensions: A Survey of Research on Problems of Ethnic, Racial, and Religious Group Relations. New York: Social Science Research Council.

Wilson, James Q. and George L. Kelling. 1982. "The Police and Neighborhood Safety: Broken Windows." The Atlantic Online March.

Wright, Talmadge. 2000. "New urban spaces and cultural representations: Social imaginaries, social-physical space, and homelessness." Research in Urban Sociology 5:23. 


\section{APPENDIX A}

Department of Sociology

Griffith University of Louisville

Bum Hunting Video Analysis 2010

13 January 2010

\section{CODING KEY}

This coding key contains codes for the analysis of the Bum Hunting Video Analysis data dealing with the seriousness, justification, dramatization, intensity, glamorization, efficacy, and attractiveness of violence portrayed in videos sampled. The data were collected from videos present on www.YouTube.com on (03/17/2010) using the search TERM "bum hunter". The unit of analysis is this key is video scenes $(\mathrm{N}=57)$. Videos were broken into scenes if there was more than one interval of violence and/or if the video creator defined separate scenes within the video by using titles or fading, or cutting away to a different location.

\begin{tabular}{|c|c|c|}
\hline $\begin{array}{l}\text { Column } \\
\text { Number }\end{array}$ & $\begin{array}{c}\text { Variable } \\
\text { Label }\end{array}$ & $\begin{array}{c}\text { Coding } \\
\text { Information }\end{array}$ \\
\hline $\mathbf{A}$ & Number & Video Number \\
\hline B & Name & The name of the video \\
\hline C & Date & Date uploaded to YouTube \\
\hline $\mathbf{D}$ & View & The number of times the video has been viewed on YouTube \\
\hline $\mathbf{E}$ & Time & The length of the video \\
\hline $\mathbf{F}$ & Violence & $\begin{array}{l}\text { Mode of violence portrayed in video } \\
00 \text { - no violence } \\
01 \text { - physical violence } \\
02 \text { - psychological violence } \\
03 \text { - physical and psychological violence } \\
99 \text { - other }\end{array}$ \\
\hline G & Physical & $\begin{array}{l}\text { Mode of physical violence portrayed in video } \\
00 \text { - no physical violence } \\
01 \text { - shooting } \\
02 \text { - threatening/forcing } \\
03 \text { - fist fighting/pushing/striking } \\
04 \text {-hitting with weapons/tools/knockout } \\
05 \text { - strangling } \\
06 \text { - poisoning } \\
07 \text { - slashing/ stabbing } \\
08 \text { - sexual violence } \\
09 \text { - kidnapping/ tying up } \\
10 \text { - arresting } \\
11 \text { - damaging property } \\
99 \text { - other }\end{array}$ \\
\hline
\end{tabular}




\begin{tabular}{|c|c|c|}
\hline $\mathbf{H}$ & Verbal & $\begin{array}{l}\text { Mode of verbal aggression } \\
00-\text { no verbal aggression } \\
01 \text { - angry talk } \\
02 \text { - use of stereotypes } \\
03 \text { - mild personal insult } \\
04 \text { - verbal threat/humiliating } \\
05 \text { - serious threatening } \\
99 \text { - other }\end{array}$ \\
\hline I & Nonverbal & $\begin{array}{l}\text { Mode of nonverbal psychological aggression } \\
00 \text { - no nonverbal aggression } \\
01 \text { - forcing/subjection/pressuring } \\
02 \text {-threatening/intimidation } \\
03 \text { - violating one's human rights } \\
04 \text { - irony/scorning gestures } \\
99 \text { - other }\end{array}$ \\
\hline $\mathbf{J}$ & Realization & $\begin{array}{l}\text { Seriousness: Realization of violence } \\
00 \text { - none } \\
01 \text { - playful aggression } \\
02 \text { - threatening/hostile gesturing } \\
03 \text { - trying to insult } \\
04 \text { - insulting } \\
05 \text { - trying to kill } \\
06 \text { - killing/suicide } \\
99 \text { - other }\end{array}$ \\
\hline $\bar{K}$ & Consequence & $\begin{array}{l}\text { Seriousness: The consequences of violence } \\
00 \text { - no consequences portrayed } \\
01 \text { - no harm } \\
02 \text { - only material harm } \\
03 \text { - mild harm/injuries } \\
04 \text { - moderate injuries } \\
05 \text { - severe injuries } \\
06 \text { - death } \\
99 \text { - other } \\
\end{array}$ \\
\hline $\mathbf{L}$ & Intention & $\begin{array}{l}\text { Justification: perceived intentionality } \\
00 \text { - no perceived justification } \\
01 \text { - intentional/internally motivated } \\
02 \text { - intentional/externally motivated } \\
03 \text { - unintentional/unconscious } \\
99 \text { - other } \\
\end{array}$ \\
\hline $\mathbf{M}$ & Motivate & $\begin{array}{l}\text { Justification: perceived motivation of violence } \\
00 \text { - no perceived motivation } \\
01 \text { - defensive - altruistic } \\
02 \text { - defensive - self-preservation } \\
03 \text { - both offensive and defensive } \\
04 \text { - offensive - instrumental } \\
05 \text { - offensive - anger } \\
99 \text { - other }\end{array}$ \\
\hline $\mathbf{N}$ & Plan & $\begin{array}{l}\text { Justification: planning of violence } \\
00-\text { unable to determine } \\
01 \text { - spontaneously produced violence } \\
02-\text { planned/systematic violence } \\
99 \text { - other }\end{array}$ \\
\hline
\end{tabular}




\begin{tabular}{|c|c|c|}
\hline 0 & Aggsex & $\begin{array}{l}\text { Justification: sex of aggressor } \\
01 \text { - male } \\
02 \text { - female } \\
03 \text { - group of males } \\
04 \text { - group of females } \\
05 \text { - males and females } \\
99 \text { - other }\end{array}$ \\
\hline $\mathbf{P}$ & Aggage & $\begin{array}{l}\text { Justification: age of the aggressor } \\
01-0-10 \text { years } \\
02-11-13 \text { years } \\
03-14-16 \text { years } \\
04-17-20 \text { years } \\
05-21-25 \text { years } \\
06-26-30 \text { years } \\
07-31-40 \text { years } \\
08-41-50 \text { years } \\
09-51-60 \text { years } \\
10-61 \text { years or older } \\
99-\text { other }\end{array}$ \\
\hline $\mathbf{Q}$ & Vicsex & $\begin{array}{l}\text { Justification: sex of victim } \\
01 \text { - male } \\
02 \text { - female } \\
03 \text { - group of males } \\
04 \text { - group of females } \\
05 \text { - males and females } \\
99 \text { - other } \\
\end{array}$ \\
\hline $\mathbf{R}$ & Vicage & $\begin{array}{l}\text { Justification: age of the victim } \\
01-0-10 \text { years } \\
02-11-13 \text { years } \\
03-14-16 \text { years } \\
04-17-20 \text { years } \\
05-21-25 \text { years } \\
06-26-30 \text { years } \\
07-31-40 \text { years } \\
08-41-50 \text { years } \\
09-51-60 \text { years } \\
10-61 \text { years or older } \\
99-\text { other }\end{array}$ \\
\hline $\mathbf{S}$ & Viotime & $\begin{array}{l}\text { Dramatization: duration of the act of violence } \\
00-\text { no violence } \\
01-1-5 \text { seconds } \\
02-6-15 \text { seconds } \\
03-16-30 \text { seconds } \\
04-30-60 \text { seconds } \\
05 \text { - more than } 60 \text { seconds } \\
99 \text { - other } \\
\end{array}$ \\
\hline $\mathbf{T}$ & Atmosphere & $\begin{array}{l}\text { Dramatization: atmosphere } \\
00 \text {-neutral or unclear } \\
01 \text {-humorous/ comic } \\
02 \text { - quarrelsome } \\
03 \text { - exciting/ adventurous } \\
04 \text { - frightening/ threatening/ horrific } \\
99 \text { - other }\end{array}$ \\
\hline
\end{tabular}




\begin{tabular}{|c|c|c|}
\hline $\mathbf{U}$ & Clarity & $\begin{array}{l}\text { Dramatization: clarity and vividness } \\
01 \text { - very unclear depiction } \\
02 \text { - unclear depiction } \\
03 \text { - clear depiction } \\
04 \text { - very clear depiction } \\
99 \text { - other } \\
\end{array}$ \\
\hline $\mathbf{V}$ & Intensity & $\begin{array}{l}\text { Intensity of violence (summative rating) } \\
00 \text { - no violence } \\
01 \text { - mild } \\
02 \text { - moderate } \\
03 \text { - brutal } \\
99 \text { - other }\end{array}$ \\
\hline$\overline{\mathbf{W}}$ & Natagg & $\begin{array}{l}\text { Glamorization: nature of aggressor } \\
01 \text { - villain } \\
02 \text { - neutral/ordinary } \\
03 \text { - hero } \\
99 \text { - other }\end{array}$ \\
\hline $\mathbf{X}$ & Natvic & $\begin{array}{l}\text { Glamorization: nature of victim } \\
01 \text { - villain } \\
02 \text { - neutral/ordinary } \\
03 \text { - hero } \\
04 \text { - animal } \\
99 \text { - other }\end{array}$ \\
\hline $\bar{Y}$ & AV & $\begin{array}{l}\text { Glamorization: audiovisual effect } \\
00 \text { - no audiovisual effects } \\
01 \text { - some audiovisual effects } \\
02 \text { - moderate audiovisual effects } \\
03 \text { - a large amount of audiovisual effects } \\
99 \text { - other }\end{array}$ \\
\hline $\mathbf{Z}$ & Igcon & $\begin{array}{l}\text { Efficacy: ignoring the consequences of violence } \\
00 \text { - no consequences depicted } \\
01 \text { - suffering emphasized } \\
02 \text { - consequences partially depicted } \\
03 \text { - consequences depicted as hints } \\
99 \text { - other }\end{array}$ \\
\hline$\overline{\mathbf{A A}}$ & Grat & $\begin{array}{l}\text { Efficacy: achieving the desired ends/gratification by violent } \\
\text { means } \\
00 \text { - no gratification } \\
01 \text { - little gratification } \\
02 \text { - partial gratification } \\
03 \text { - complete gratification } \\
99 \text { - other }\end{array}$ \\
\hline AB & Attract & $\begin{array}{l}\text { Attractiveness of violence (summative rating) } \\
00 \text { - unattractive } \\
01 \text { - moderate/neutral } \\
02 \text { - attractive } \\
99 \text { - other }\end{array}$ \\
\hline
\end{tabular}




\section{CIRCIULUM VITAE}

NAME: $\quad$ Elizabeth Anne Griffith

ADDRESS: 1162 Nancy Lee Lane

Cincinnati, OH 45238

DOB: $\quad$ Cincinnati, Ohio - May 4, 1986

EDUCATION

\& TRAINING: $\quad$ B.A. Sociology/Anthropology

Ohio Wesleyan University

2004-2008

PROFESSIONAL SOCIETIES: Alpha Kappa Delta

Mid-South Sociological Association 